\title{
PLANATION SURFACES IN THE POLISH CARPATHIANS: MYTH OR REALITY?
}

\author{
WITOLD ZUCHIEWICZ \\ AGH University of Science and Technology, Faculty of Geology, \\ Geophysics and Environmental Protection, \\ Al. Mickiewicza 30, 30-059 Kraków, Poland \\ E-mail: witoldzuchiewicz@geol.agh.edu.pl
}

\begin{abstract}
Previous views concerning the number and age of planation surfaces in the Polish segment of the Carpathians varied depending on the state of recognition of geological structure of the area. The most commonly accepted opinion says that at least three such surfaces, representing remnants of pre-existing landscapes, can be traced in the study region. These include the intramontane (Early Pliocene), foothills (Late Pliocene) and riverside (Early Pleistocene) levels. Scarce fission track data pertaining to the age of exhumation of the Carpathian orogen indicate that the preserved "planation surfaces" could not had formed before ca. $7 \mathrm{Ma}$. A possibility exists, however, that individual bevels could have been shaped at the same time at different altitudes, with respect to local base levels and differentiated bedrock resistance to erosion.
\end{abstract}

Key words: planation surfaces, exhumation, Carpathians, Poland

\section{INTRODUCTION}

Planation surfaces, defined as "topographic surfaces which are nearly flat over longer distances" (Migoń, 2004b, p. 788) showing, however, some minor relief, include peneplains, pediplains, etchplains, abrasion platforms, as well as plains formed by frost processes in the periglacial zone (altiplanation surfaces), glacial erosion, or salt weathering (Adams, 1975; Fairbridge and Finkl, 1980; Twidale, 1983; Phillips, 2002; Migoń, 2004a,b; White, 2004b; Allen, 2008 and references therein). It is commonly accepted nowadays that plains of long geomorphic history, like peneplains or pediplains, represent mostly polygenetic surfaces which have been moulded by various processes, not necessarily during prolonged periods of tectonic quiescence and at different altitudes with respect to the base level (Willet et al., 2001; Migoń, 2004a,b; Babault et al., 2007;
Pelletier, 2010). Babault et al. (2007) even postulated that erosion surfaces tend to develop during tectonic convergence.

Low-relief areas in mountain ranges are either pre-orogenic, synorogenic or post-orogenic (Calvet and Gunnell, 2008). Elevated erosion surfaces in active orogens have traditionally been interpreted as uplifted peneplains (Davis, 1911), the origin of which required recent surface uplift of the pre-existing landscape (Clark et al., 2005). It is likely, however, that such surfaces may form at different elevations and that scattered bevels could have been shaped locally and independently of one another (e.g., Gubbels et al., 1993). A recent study of uplifted planar topography of the East Pyrenees has shown that it is a palaeosurface that graded to local base levels via low-gradient piedmonts and formed at elevations exceeding $1,000 \mathrm{~m}$ a.s.1., being later further uplifted and dissected (Calvet and Gunnell, 2008). 

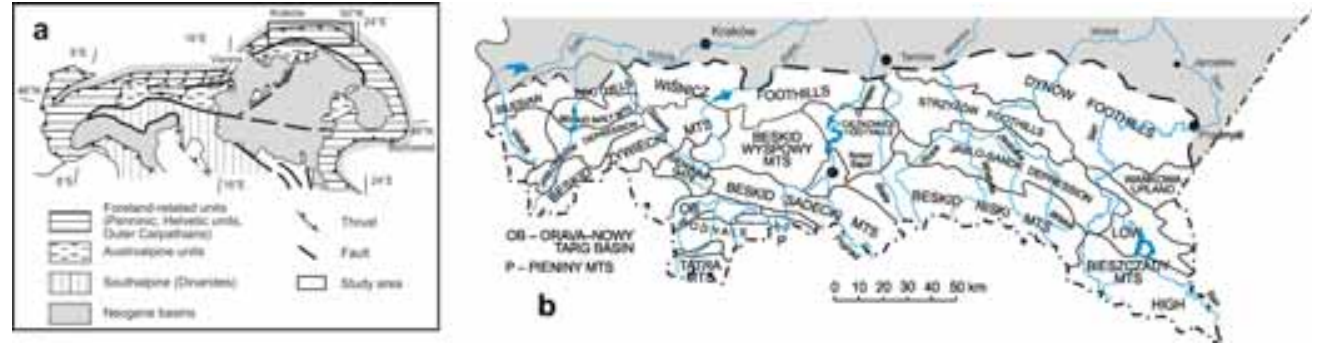

Figure 1. Location of the study area

a - simplified tectonic sketch of the Alpine-Carpathian chain (based on Neubauer et al., 1997; modified); b - geomorphic subdivision of the Polish Carpathians (based on Starkel, 1991).

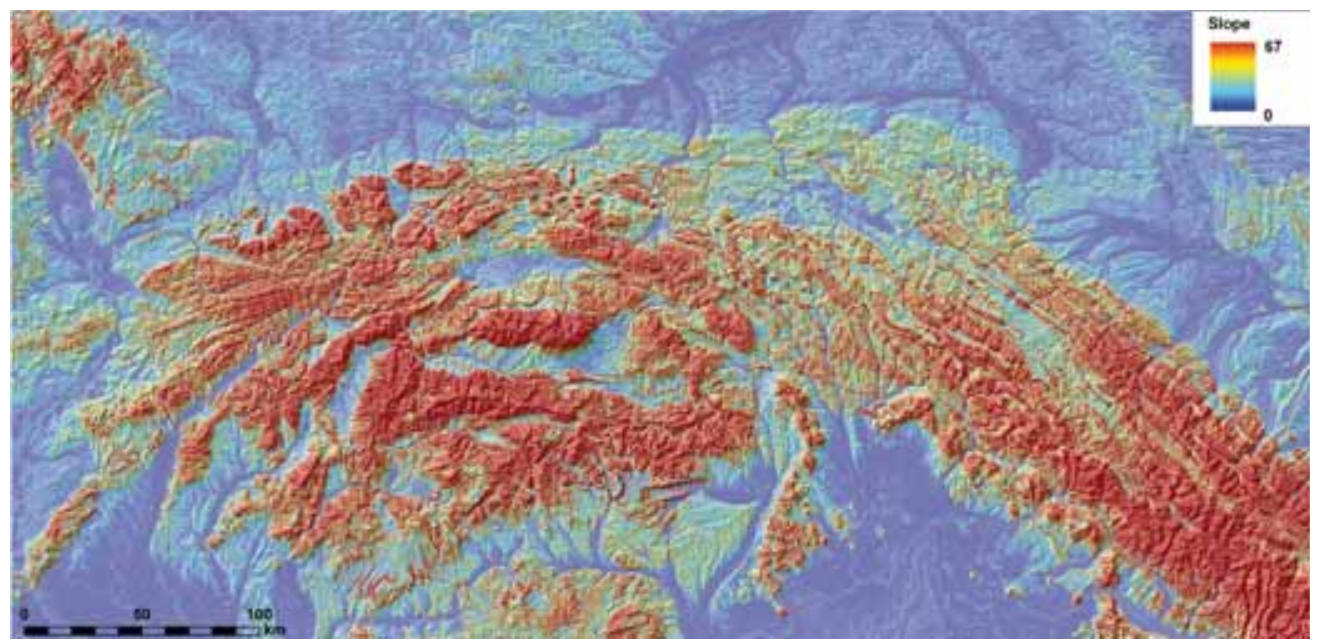

Figure 2. Digital elevation model of the northern part of the Carpathians showing areas typified by different slope values (elaborated by J. Zasadni).

The aim of this paper is to give a short overview of different concepts pertaining to the origin, number and age of "planation surfaces" in the Polish Carpathians (Figs 1, 2).

\section{PLANATION SURFACES IN THE POLISH CARPATHIANS}

Traditional geomorphic studies in the Carpathians aimed at reconstructing long-term development of landforms basing on analysis of deformed planation surfaces, drainage pattern changes, deformation of fluvial terraces and diversified thicknesses of Quater- nary sediments infilling young sedimentary basins. The patterns of drainage systems and principal geomorphic units used to be related to transversal undulations of the orogen (W. Teisseyre, 1921; H. Teisseyre, 1928; Świderski, 1934-35; Klimaszewski, 1965; cf. Fig. 3) and structural style of individual nappes as well as bedrock resistance (Starkel, 1969b, 1972; Henkiel, 1977), while neotectonic (Pliocene-Quaternary) deformations were associated with large-scale, asymmetric dome-like uplift of the Carpathians with the Tatra massif in their central part (Klimaszewski, 1966; Książkiewicz, 1972; Mazúr, 1979; Lacika and Urbánek, 1998; 


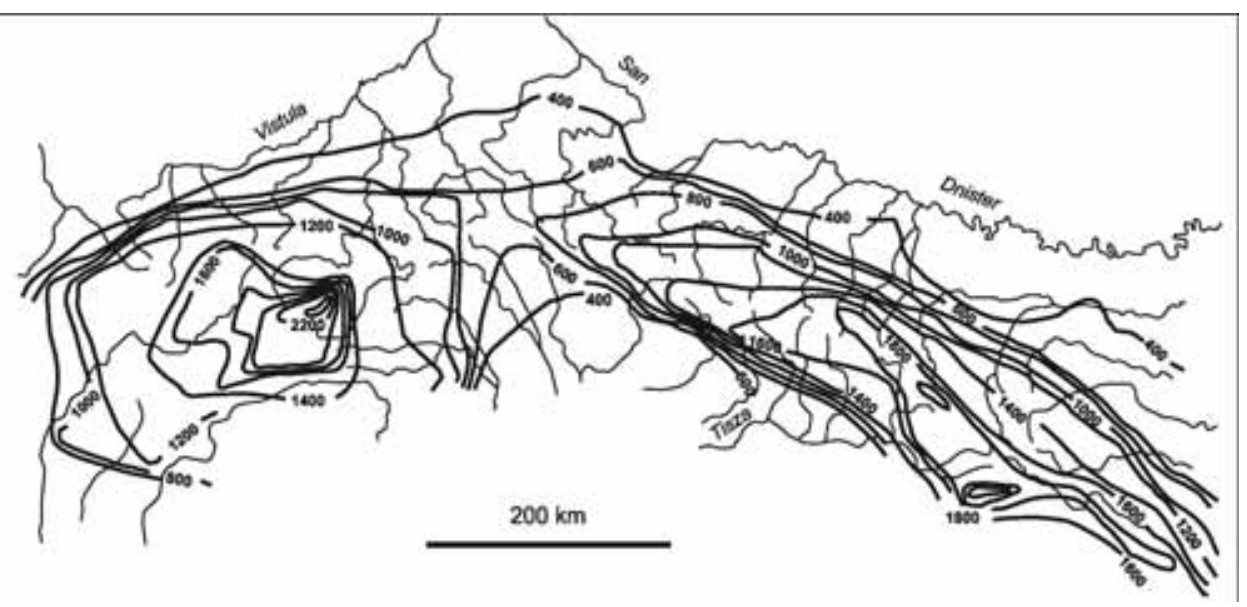

Figure 3. Summit surface of the Northern Carpathians

(after H. Teisseyre, 1928; see also Zuchiewicz, 1995; modified).

Lacika, 2004), or with block-type motions (Bashenina et al., 1969; Fusan et al., 1979).

Neogene tectogenesis of the Northern Carpathians (Książkiewicz, 1972; Tokarski, 1978; Jiřiček, 1979; Fodor et al., 1999; Oszczypko et al., 2005, 2008; Kovač et al., 2007; Golonka et al., 2009 ) indicates that relief development was not at all isochronous, as it was suggested in previous papers. The main episodes of overthrusting in the Outer Western Carpathians (OWC) in Poland took place after the Ottnangian and before the Karpatian, during the late Badenian, and after the Sarmatian, proceeding with a mean rate of $12 \mathrm{~mm} / \mathrm{yr}$ during $7 \mathrm{~m} . \mathrm{y}$. time span (Karpatian-Sarmatian; cf. Oszczypko et al., 2005). Recent studies indicate that thrusting was also active after the Pannonian in the western portion of the area (Wójcik and Jugowiec, 1998).

During the Neogene, the size of erosional dissection of the OWC amounted to 280-400 $\mathrm{m}$, increasing to $820-1,000 \mathrm{~m}$ in the Eastern Carpathians (Zuchiewicz, 1984a,b). The coeval subsidence of individual basins in the Inner Carpathians of Poland exceeded, in turn, $1,000 \mathrm{~m}$ being accompanied by ca. 200-550 $\mathrm{m}$ uplift of the surrounding mountain ranges.

Following traditional opinions, the OWC landscape is dominated by at least four ero- sion surfaces ("planation surfaces") that were mainly shaped due to planation proceeding upstream along the main river valleys, usually owing to lateral slope retreat (Sawicki, 1909; Klimaszewski, 1934, 1965; cf. Fig. 4). The evolution of the landscape was mainly controlled by differentiated bedrock resistance to erosion as well as by young tectonic movements that prevented development of fully developed, "mature" planation surfaces (Fig. 5). The preserved fragments of individual bevels represent remnants of pre-existing hilly landscape of relief energy ranging between $50-80 \mathrm{~m}$ and ca. $100 \mathrm{~m}$. Proceeding from the Carpathian margin towards the south, bevels of increasing height and age tend to appear.

The oldest Beskidy level (Sawicki, 1909) is to be found upon planar mountain ridges showing uniform long profiles. It cuts resistant, thick-bedded sandstone complexes in the westernmost part of the OWC in Poland. The altitudes of this level change from 1000$1200 \mathrm{~m}$ a.s.l. in the Silesian and Sądecki Beskid Mts. to 800-900 m a.s.l. in the Beskid Mały Mts., and it is dissected by 200-500 m deep valleys. Different heights of preserved fragments of this level used to be explained by subsequent tectonic reorganization (cf. Stehlik, 1964, 1965; Mazúr, 1963, 1965, 1979; Malarz, 1974; Malarz and Ziętara, 1975; 


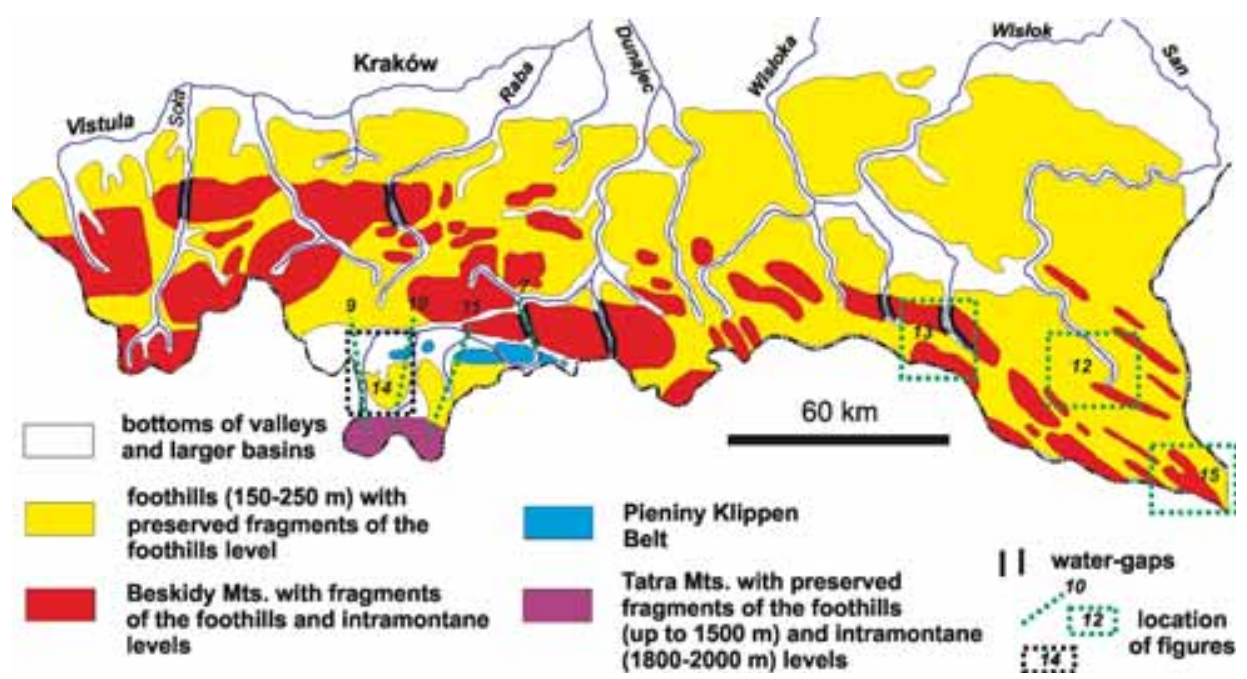

Figure 4. Geomorphic sketch-map of the Polish Carpathians (based on Klimaszewski, 1965, 1967; modified).

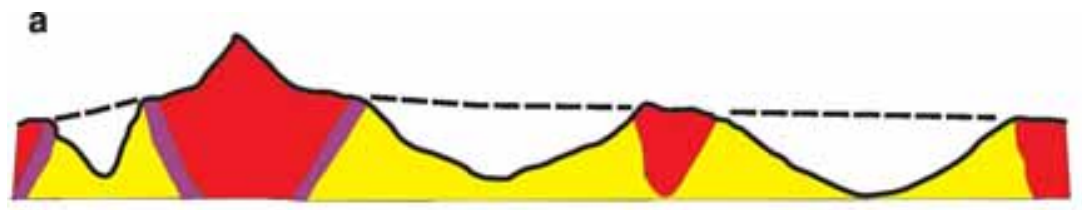

b

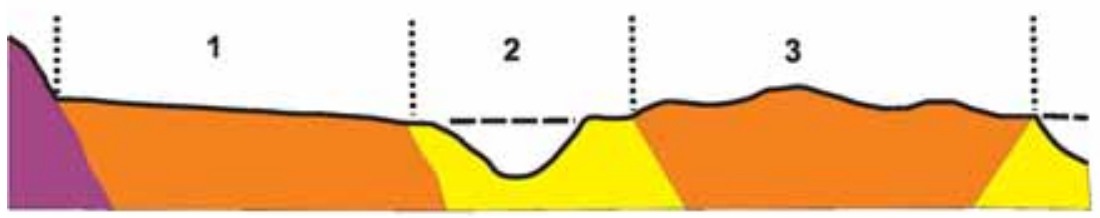

c
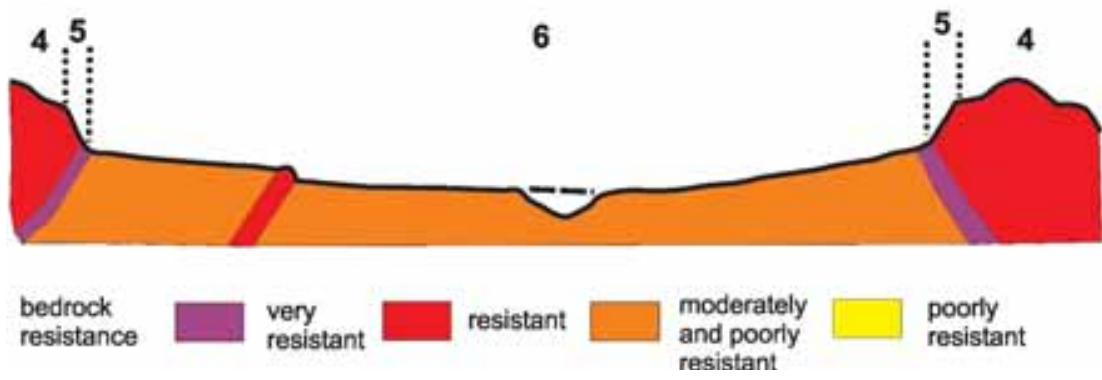

Figure 5. Types of morphology of planation surfaces in the Polish Outer Carpathians (based on Henkiel, 1969, modified; cf. also Zuchiewicz, 2010)

a - intramontane level, b - foothills level, c - riverside level; 1 - soft-rock pediments (glacis), 2 - erosion surfaces, 3 undulated denudation plains, 4 - remnants of pre-existing relief, 5 - denuded slope, 6 - pediments. 
Baumgart-Kotarba et al., 1976). It is difficult to decide, however, whether these fragments really represent remnants of a former planation surface or are bevels controlled by low-resistant bedrock or subhorizontally dipping strata. Some authors questioned the presence of such a level in the Polish Carpathians (Starkel, 1972, 1975).

The younger intramontane level (Klimaszewski, 1934) cuts both strongly and moderately resistant flysch strata. It forms vast flat areas present within high foothills, rocky benches surrounding mountain ranges and planar interfluves (Figs 4, 5). The altitudes change from $450-500 \mathrm{~m}$ a.s.l. within the foothills to $700-1000 \mathrm{~m}$ a.s.l. in the Beskidy Mts., whereas relief energy values are between $230-250 \mathrm{~m}$ and $300-500 \mathrm{~m}$. The origin of this level used to be assigned to planation processes active in semi-arid climate (Klimaszewski, 1934; Starkel, 1965, 1969b, 1975, 1976; Baumgart-Kotarba et al., 1976; Henkiel, 1977); some authors took also into account lateral river erosion (Činčura, 1967; Harčar, 1975; Mazúr, 1965; Mazúr and Činčura, 1975).

The foothills (submontane) level (Klimaszewski, 1934) rises 360-420 m a.s.l. in the Carpathian Foothills and 600-800 m a.s.l. in the Beskidy Mts., truncating strata of variable resistance to erosion (Figs 4, 5). It can be traced along main Carpathian valleys up to interfluve areas, showing properties of a late-mature landscape (Starkel, 1965, 1969b, 1972, 1975, 1976; Baumgart-Kotarba et al., 1976; Henkiel, 1977, 1977-78). This level is developed best upon exposures of moderately-resistant rocks. The amount of erosional dissection changes from 150-200 $\mathrm{m}$ in axial parts of neotectonically elevated areas to $120 \mathrm{~m}$ in the foothills. In the latter area as well as in intramontane basins, it is considered to represent a fully developed "planation surface" (Starkel, 1965; Henkiel, 1977), while in higher elevated ranges this level resembles a hilly, undulating landscape upon interfluves or erosional breaks of slope on valley sides (Henkiel, 1977-78). At the feet of isolated mountain massifs, however, the level remnants are composed of either flat or bevelled "true" pediments or soft-rock pediments (glacis d'erosion; cf. Twidale, 1978; Oberlander, 1989; White, 2004a,b). According to Klimaszewski (1934, 1937) and Starkel (1965, 1969b, 1972, 1975), the level originated due to pediplanation in a semi-arid climate, while Henkiel (1969, 1977-78) suggested prevalence of a warm and moist climate suitable for intensive chemical weathering. The inferred size of uplift of this level was to be strongest in the Beskidy Mts. and least intensive in the

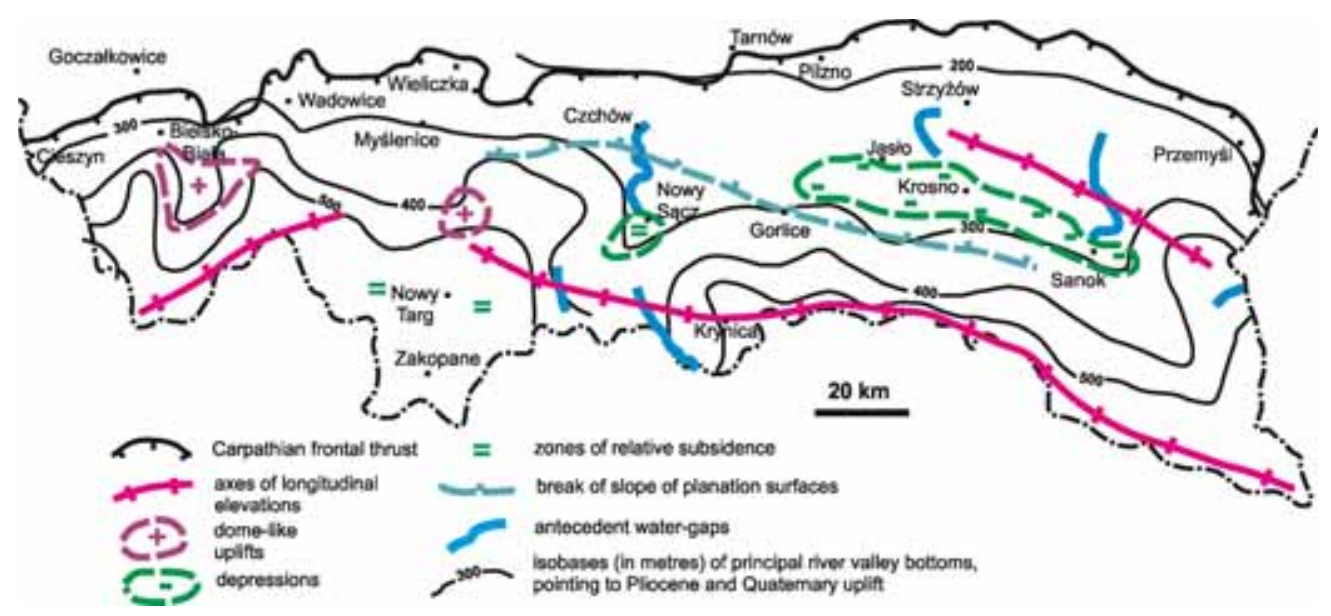

Figure 6. Neotectonic sketch-map of the Outer Carpathians of Poland (based on Klimaszewski, 1965; modified by Starkel, 1972). 
Jasło-Sanok Depression (Klimaszewski, 1965; Starkel, 1972). Worth noting is a drop in elevation of the foothills level on the northern margin of the Beskid Niski Mts., in a zone considered by Starkel (1972, 1975, 1976) a "young tectonic line" that continues farther west into the Rożnów - Żegocina Wiśniowa zone (Fig. 6).

The youngest riverside level (,poziom przydolinny" in Polish - a name coined by Starkel in 1965 for a Slovak term ,poriečna uroveň" introduced by Mazúr in 1963; see also "Nockowa level" of Starkel, 1957, 1969a,b and compare: Mazúr, 1979; Minár et al., 2004) is ubiquitous within low foothills composed of poorly-resistant rocks (Figs 4, 5). Vast surfaces occupied by this level dominate the landscape of the Jasło-Sanok Depresssion, where lateral erosion was thought to have been the most influential relief-forming agent (Fleszar, 1914). At the feet of the Silesian and Mały Beskid Mts., the level represents soft-rock pediments (Starkel, 1972), while in the main OWC valleys it can be correlated with few levels of strath terraces (Henkiel, 1969, 1977-78; Zuchiewicz, 1984a, 1988, 1989, 1991, 1995). The altitudes rise from 290-320 m a.s.l. in the Carpathian marginal zone to $500-600 \mathrm{~m}$ a.s.l. in the Beskidy Mts., and even to $700 \mathrm{~m}$ a.s.l. in the Bieszczady Mts. in the eastern portion of the Polish Carpathians (Starkel, 1972). Relief energy values tend to increase to the south and east, from $40-50 \mathrm{~m}$ to $80-110 \mathrm{~m}$, dropping in the Jasło-Sanok Depression to $30-70$ $\mathrm{m}$. The highest figures typify the Beskid Sądecki Mts. dissected by the Dunajec River water-gap (cf. Figs. 7, 8; Zuchiewicz, 1983, 1984a). The evolution of riverside level used to be associated with semi-arid climate characterised as well by episodic intensive rainfalls suitable for slopewash processes. Such a view resulted from a dominating in these times concept of coeval formation of the riverside level and deposition of coarse-clastic, Villafranchian-type deposits of the Witow Series in front of the Carpathians (Dżułyński et al., 1968; Starkel, 1969a,b; Henkiel, 1977). Recent revision of the age of this series, based on macro-plant determina- tion (Middle-Late Miocene; cf. Brud and Worobiec, 2003; Brud, 2004), contradicts such an hypothesis.

A summary of different views on the number and age of planation surfaces in the Czech, Slovak, Polish and Ukrainian Carpathians is provided in papers by Zuchiewicz (1995, 2009, 2010).

\section{PLANATION, EROSION AND UPLIFT IN THE LIGHT OF PREVIOUS STUDIES}

Rudnytsky (1905), Romer (1907), Smoleński (1911) and Fleszar (1914) claimed that the Carpathian drainage network became increasingly more controlled by underlying geological structures owing to epigenesis, via formation of a peneplain and its subsequent dissection upon exposures of poorly-resistant rocks. Rudnytsky (1905) assumed the presence of a vast peneplain in the western part of the Dnister River drainage basin and concluded about minor Pliocene uplift, later replaced by strong Pleistocene exhumation. Romer (1907), in turn, maintained that the strongest surface uplift preceded the Pleistocene. Sawicki (1909) put forward an hypothesis that peneplain already disappeared in the Pliocene and that the most significant exhumation took place in the Sarmatian, while Pokorny (1911) concluded about intensive planation in Sarmatian time being succeeded by uplift in the Pliocene. Świderski (1934-35) distinguished two and three pre-Badenian erosional cycles in the Western and Eastern Carpathians, respectively.

Sawicki (1909) described two planation surfaces formed at the turn of the Oligocene and Miocene and before the Badenian. This view was questioned by Pawłowski (1916) who inferred a post-Miocene age of these surfaces. H. Teisseyre (1928) considered the „summit surface” of the Outer Carpathians (Fig. 3) a typical structural feature reflecting both exposures of resistant strata and variable rates of tectonic movements. A few years later, Klimaszewski (1934, 1937) and Smoleński (1937) distinguished the Early Sarmatian intramontane level (rising 230- 

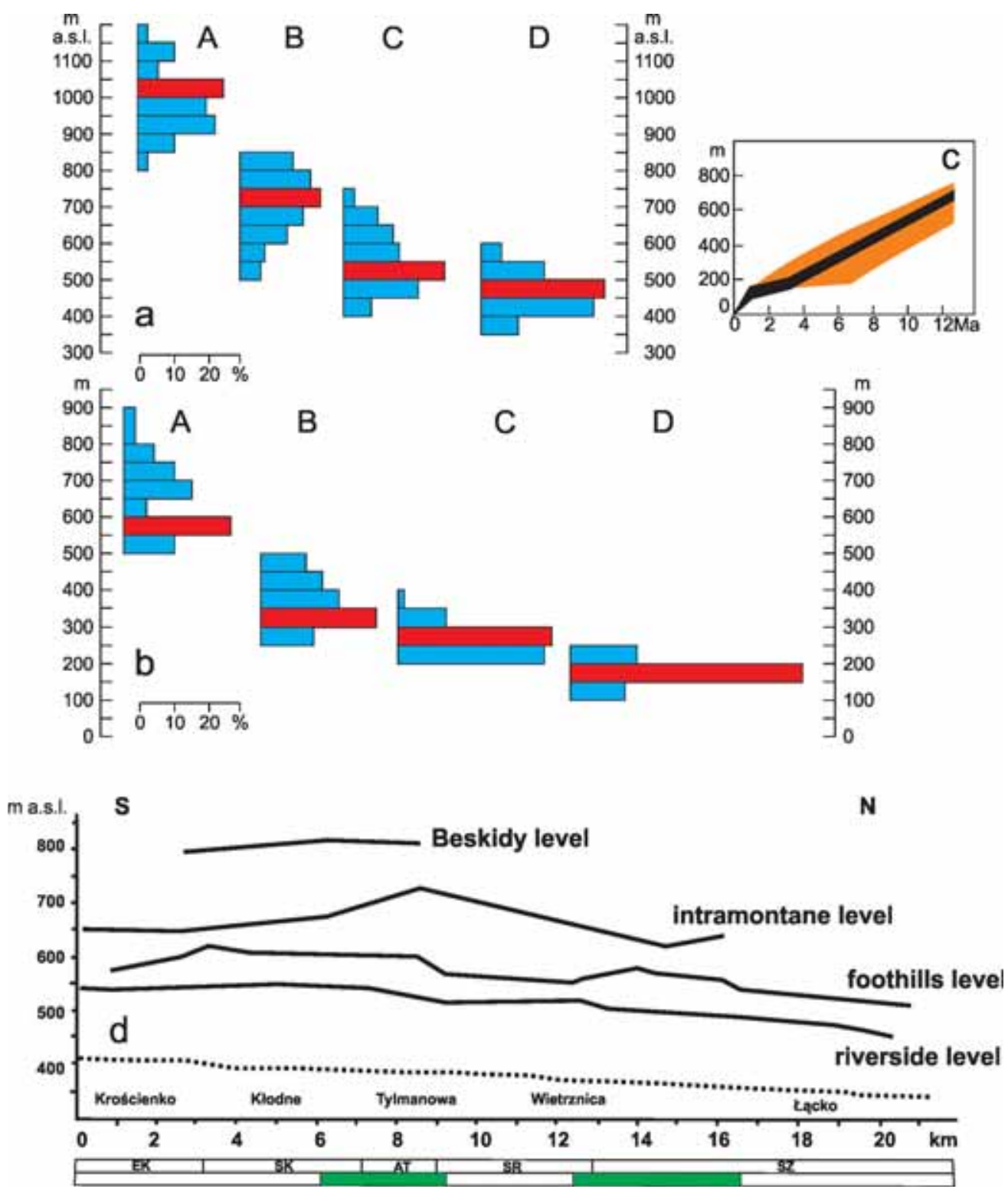

Figure 7. Diagrams portraying altitudes of the preserved fragments of planation surfaces in the medial portion of the Dunajec River drainage basin, Beskid Sądecki Mts. (based on Zuchiewicz, 1995, 2010 and Łój et al., 2009; modified)

A - Beskidy level (middle-late Serravallian), B - intramontane level (early-middle Tortonian), C - foothills level (Piazenzian), D - riverside level (Early Pleistocene); a - altitude above the sea level, b - altitude above recent floodplain, $\mathrm{c}$ - rates of erosional dissection (showing also uncertainty intervals), $\mathrm{d}$ - long profiles in the Dunajec River water-gap. Tectonic units: EK - Krościenko Elevation, SK - Kłodne Syncline, AT - Tylmanowa Anticline, SR - Rzeka Syncline, SZ - Sobel-Zabrzeż Anticline. Green fields denote zones of long profile disturbance. See Fig. 4 for location. 

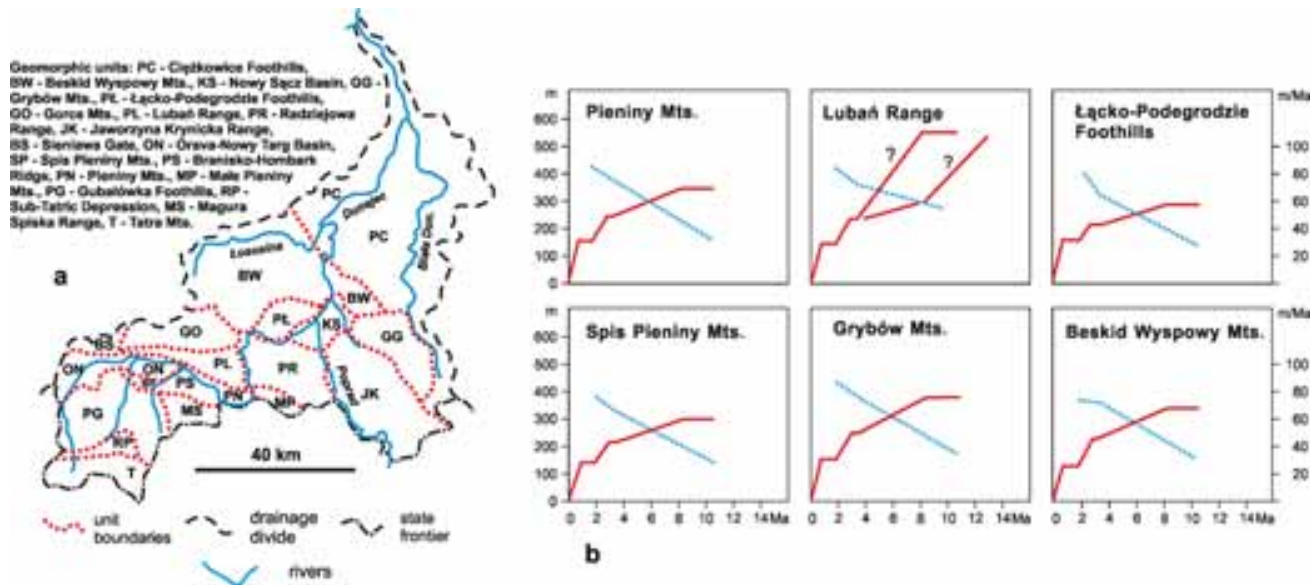

Figure 8. Geomorphic subdivision (a; based on Krawczyk and Zuchiewicz, 1989; modified) and amount of erosional dissection (b; based on Zuchiewicz, 1984b, 1995, 2010; modified) of planation surfaces in selected regions: solid lines denote the size and dotted lines portray rates of dissection on Bubnoff diagrams.

$260 \mathrm{~m}$ above recent valley bottoms) and the Early Pliocene foothills level $(120-150 \mathrm{~m})$. A concept of the Sarmatian age was based on the then dominating view of the Late Badenian age of Sarmatian molasses filling the Carpathian Foredeep Basin. Another concept was later presented by Starkel (1957, 1969b, 1972) who assigned the intramontane (250-400 m), foothills, and riverside levels the Early Pliocene, Late Pliocene, and Early Pleistocene ages. This view was upheld by Zuchiewicz (1978) in respect to the Beskid Sądecki Mts. In the Slovak Carpathians, Lukniš $(1962,1964)$ distinguished two (Sarmatian-Pannonian, Late Pliocene), and Mazúr $(1963,1965)$ - three planation surfaces (Tortonian-Early Sarmatian, Pannonian, Late Pliocene).

Arguments in favour of post-Sarmatian age of thrusting east of the Dunajec River valley in the OWC (Obuchowicz, 1963; Cisek and Czernicki, 1964; Książkiewicz, 1972; Połtowicz and Starczewska-Popow, 1973; Połtowicz, 1974) led Starkel (1969b, 1972, 1975) to hypothesize about Pliocene ages of planation surfaces situated below the Beskidy level. Velikovskaya (1968), in turn, reconstructed only one, much more younger than Badenian, planation surface in the Eastern Carpathians. This surface was thought to have been uplifted and faulted during Late Pliocene and Early Pleistocene times. Another view was presented by Demediuk $(1983,1994)$ who distinguished in the Eastern Carpathians four planation surfaces shaped in the Karpatian (Połoniny level), Pontian (Beskidy level), Late Pliocene (upper riverside level; Krasna/Skrideisky levels), and Early Pleistocene (lower riverside level; Loyova, Boroniava/Kopan' levels).

Geomorphic studies conducted by Zuchiewicz (1980, 1984b) in the Pieniny and Beskid Sądecki Mts. led to a conclusion that the Beskidy level originated in the Early Sarmatian, and was later successively dissected and faulted during the Early Pannonian „Moldavian phase”. The younger intramontane and foothills levels were, hence, assigned the Pannonian and Romanian ages. The amount of exhumation inferred from the size of erosional dissection of individual levels in the Dunajec River drainage basin (Figs 7, 8) was estimated at: 220-360 m (Early Pannonian), 75-320 m (Dacian), and 30-150 m (Romanian/Early Pleistocene; cf. Zuchiewicz, 1984a,b), respectively. Baumgart-Kotarba $(1973,1974)$ distinguished five ridge levels rising above the foothills level; 


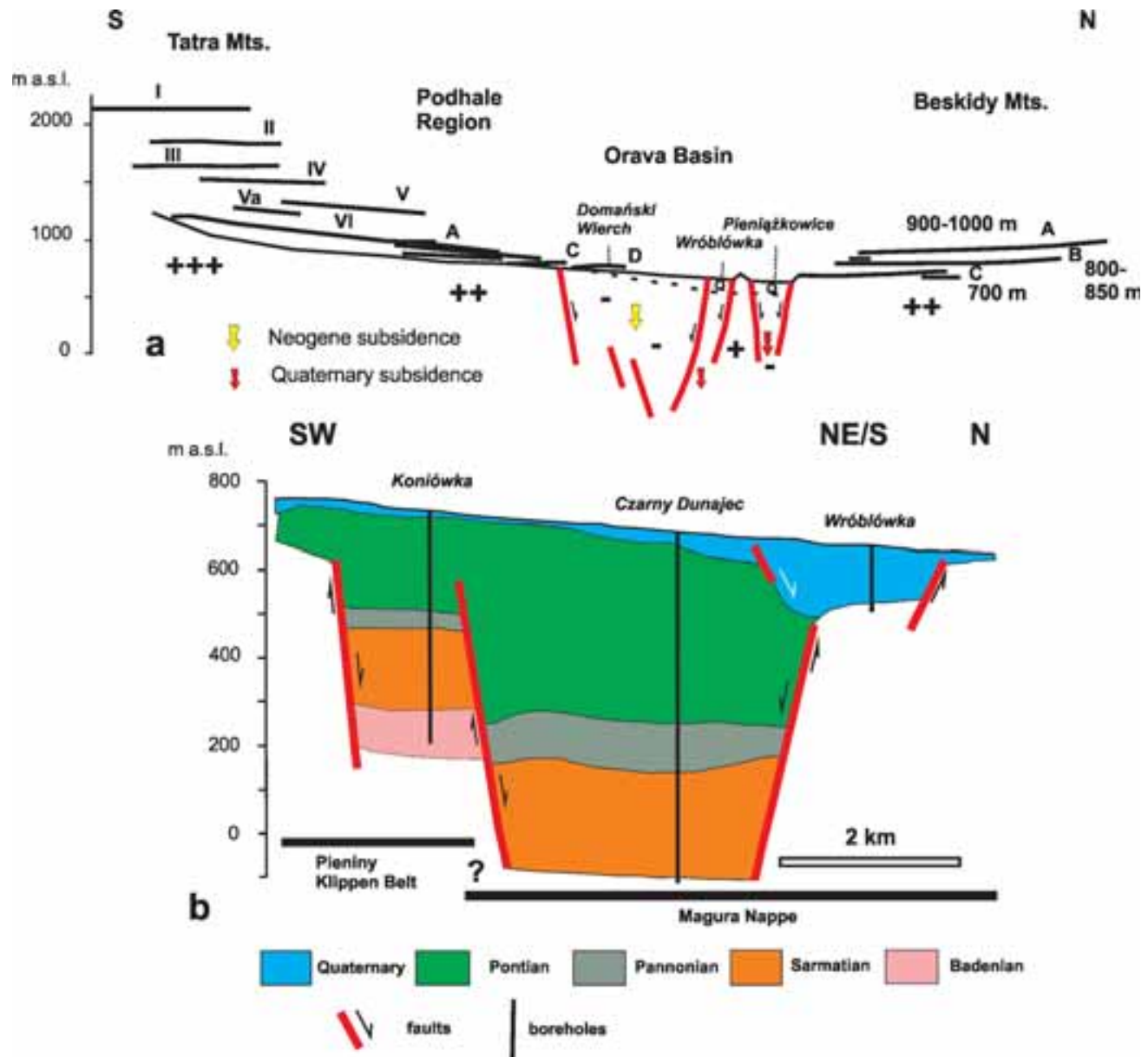

Figure 9. Cross-sections through the Orava Basin (cf. Łój et al., 2009)

a - planation surfaces on a simplifed section across the Tatras, Orava Basin and Orava Foothills (based on Baumgart-Kotarba, 1983, redrawn in supplemented form by Mojski, 2005; modified); sign “+” denotes relative intensity of uplift; b - section across the Orava Basin (after Pomianowski, 2003; modified); vertical lines denote boreholes. Both sections are of different scales. See Fig. 4 for location.

hence, the number of levels increased to seven.

Another picture represents the Polish segment of the Inner Carpathians where five to six levels were distinguished in the Tatra Mts. (Klimaszewski, 1988; Bąk, 1989) and four in Podhale region: $1200-1150 \mathrm{~m}$ a.s.l. (level A; Pannonian?), 1000-900 m a.s.l. (level B; Pontian?), 850-770 m a.s.l. (level C; Dacian?), and 750-660 $\mathrm{m}$ a.s.l. (level D; Early Pleistocene; cf. Baumgart-Kotarba, 1983, 1996). These levels, markedly lowered in the axial part of the Orava - Nowy Targ Basin (Figs 9-11), have their higher-situated age equivalents on the southern slopes of the Beskid Sądecki Mts. (Baumgart-Kotarba, 1983).

Few authors attempted at reconstructing palaeomorphology of individual levels (Starkel, 1965, 1966; Henkiel, 1969, 1977; Zuchiewicz, 1988; cf. Figs 12, 13). The most detailed reconstruction by Starkel (1965) was an effect of careful mapping of interfluve landforms in the upper San River 


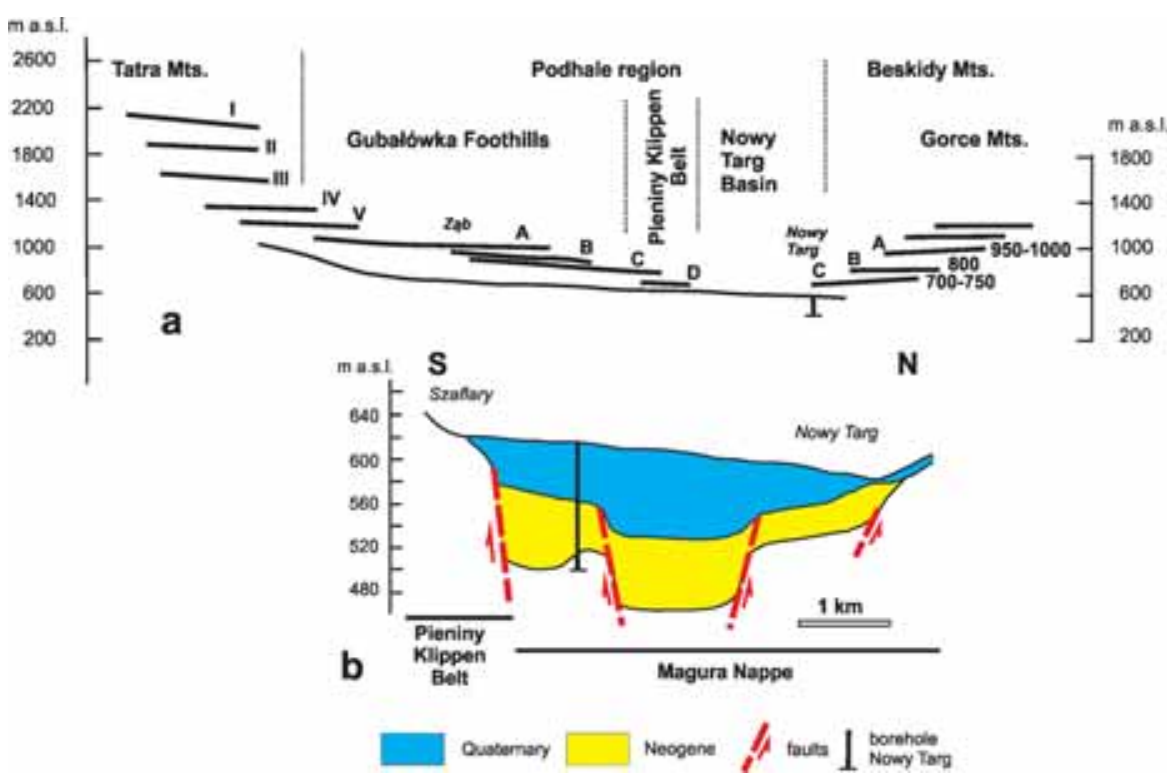

Figure 10. Cross-sections through the Nowy Targ Basin

a - planation sufaces on a simplified section across the Tatras, Podhale region, Nowy Targ Basin and Gorce Mts. (based on Baumgart-Kotarba, 1983; modified); b - section across the Nowy Targ Basin (after Pomianowski, 2003; modified). Note that both sections are of different scales. See Fig. 4 for location.

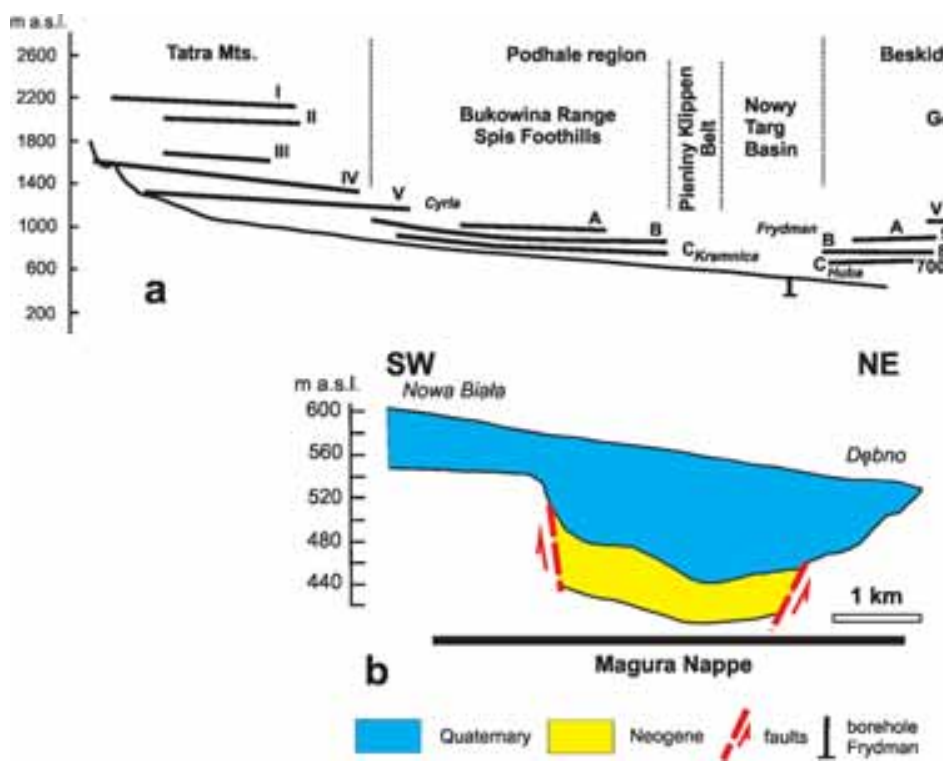

Figure 11. Cross-sections through the eastern portion of the Nowy Targ Basin

a - planation sufaces on a simplified section across the Tatras, Podhale region, Nowy Targ Basin and Gorce Mts. (based on Baumgart-Kotarba, 1983; modified); b - section across the Dębno-Frydman Graben (after Pomianowski, 2003; modified). Note that both sections are of different scales. See Fig. 4 for location. 
drainage basin that made it possible to present the landscape of individual levels being later remodelled due to differentiated bedrock resistance (Fig. 12). None of these hypotheses, however, explains the presence of
Badenian molasses preserved in river valleys of the East Carpathian foothills (cf. Rajchel, 1976; Cieszkowski et al., 1977); a fact that led A. Wójcik (in: Cieszkowski et al., 1977) to consider the foothills level an abrasion

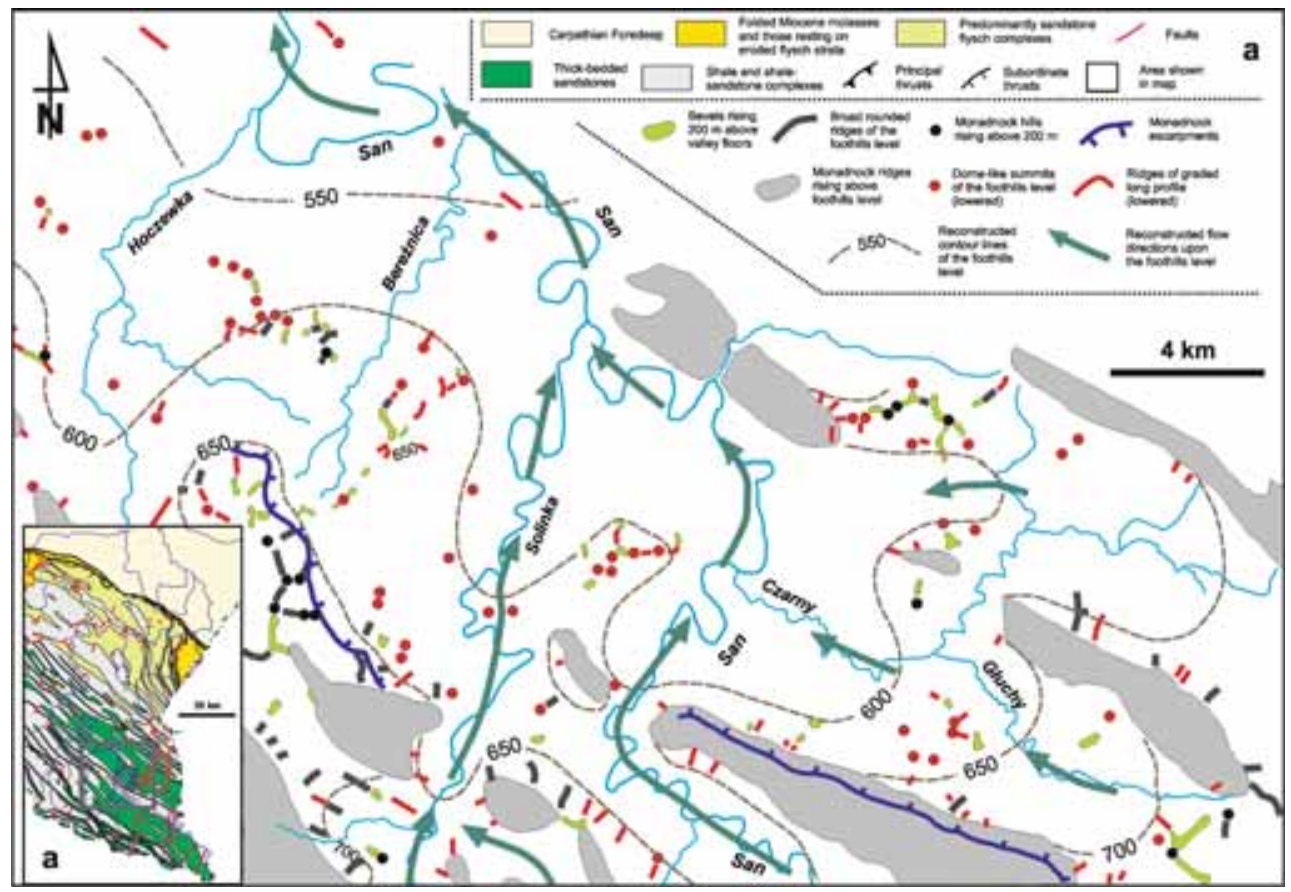

Figure 12. Palaeogeomorphic map of the foothills level in the Bieszczady Mts., Outer Eastern Carpathians of Poland (based on Starkel, 1965; simplified and modified)

a - inset showing map of rock resistance in the eastern portion of the Polish Carpathians (based on different authors, redrawn from Zuchiewicz and Zasadni, 2010). See Fig. 4 for location.
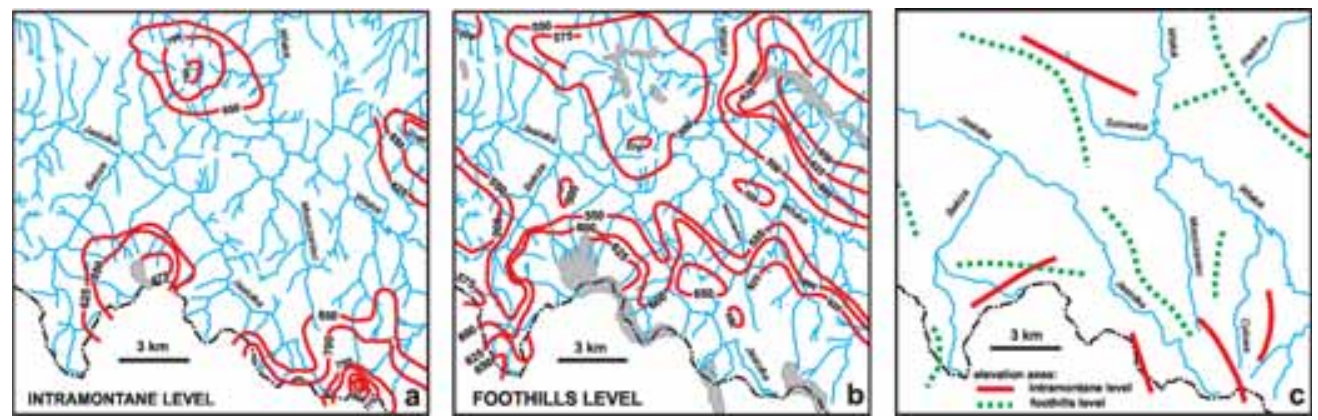

Figure 13. Reconstructed topography of intramontane (a) and foothills (b) planation surfaces in the eastern Beskid Niski Mts., and their elevations (c); based on Zuchiewicz (1988); modified. See Fig. 4 for location. 
surface of the Early Badenian sea, dissected and deformed during subsequent tectonic movements (see also Wójcik, 2003).

\section{PALAEOGEOGRAPHICAL IMPLICATIONS}

A review of palaeogeographical studies of Miocene molasses filling the Carpathian Foredeep Basin led Zuchiewicz (1987a,b) to distinguish approximately ten episodes of intensive erosion between the Middle Egerian and Romanian, separated by relatively short "quiescent" intervals lasting 1 to 3 m.y. It is likely, therefore, that in the Neogene long-term, uninterrupted development of "planation surfaces" was impossible. The intramontane and foothills levels were usually considered pediments. The development of the latter necessitates the presence of arid or semi-arid climate with episodic torrential rainfalls destroying vegetation cover, suitable for intensive weathering, and active during prolonged periods of tectonic quiescence. Pécsi et al. (1985) and Pécsi (1994) estimated the duration of Late Neogene pedimentation in Hungary at 5 to 2.5 m.y. Comparable conclusions can be drawn from palaeoclimate reconstructions (e.g., Łańcucka-Środoniowa, 1963, 1979; Oszast and Stuchlik, 1977; Stuchlik, 1980; Kvaček et al., 2006), which exclude a possibility of Neogene development of typical pediments, except in the Early Miocene. The only Neogene stages, the duration and climate of which could have been suitable for planation processes, were: Kosovian and/or Early Sarmatian, Pannonian, and - in part - Pontian and Romanian. One can not exclude, however, that individual bevels could have formed at the same time at different altitudes upon exposures of moderately and poorly resistant strata. These bevels could have been separated by exposures of resistant rocks that formed local bases of erosion. It was already suggested for some areas (cf. Bieszczady Mts.) that all „planation surfaces” represent structural surfaces formed on gently /subhorizontally dipping and/or poorly resistant strata (Tokarski, 1975).

\section{DISCUSSION}

A concept of development of several planation surfaces preserved upon exposures of strata showing differentiated resistance to erosion, and deformed during few „orogenic phases" remained in geomorphic literature till the end of the 1980s. Four and four to six planation surfaces were distinguished in the Outer and Inner Carpathians, respectively (cf. Starkel, 1972, 1988; Baumgart-Kotarba, 1983; Zuchiewicz, 1984a,b; Gilewska, 1987; Klimaszewski, 1988), although the lack of correlative sediments made age determination of individual surfaces impossible. The last exchange of views between adherents of two contradictory evolutionary concepts took place in years 1987-1988 (Klimaszewski, 1987; Starkel, 1988); later case studies concerned several regions in the Inner (i.a., Kukulak, 1991, 1993; Bac-Moszaszwili, 1993, 1995; Fig. 14) and Outer Carpathians (Bieszczady Mts.; Kukulak, 2004; Haczewski et al., 2007; Fig. 15). In the last decade the problem re-appears in geomorphic literature following the advent of new research methods (Starkel, 2003; Minár et al., 2004; Danišík et al., 2008). Some authors, however, completely negate a possibility of development of Miocene planation surfaces in the OWC, taking into account the size of eroded overburden, which, for instance in the Belokarpatská Unit of the Magura Nappe (Czech Republic), amounted to $1.4 \mathrm{~km}$ (cf. Bíl et al., 2004). In this case, intensive erosion should have generated passive isostatic rebound that led to a state of dynamic equilibrium between uplift and denudation. The landscape, therefore, could have developed nearly continuously, without being interrupted by prolonged episodes of planation. I am inclined to support such a view.

Numerous pieces of evidence in favour of nearly continuous tectonic mobility of the OWC nappes in the Neogene (Oszczypko and Ślączka, 1985; Oszczypko, 1996, 1997; Kováč, 2000; Oszczypko et al., 2005, 2008) contradict a concept of uninterrupted development of "planation surfaces" during prolonged periods of tectonic quiescence. 


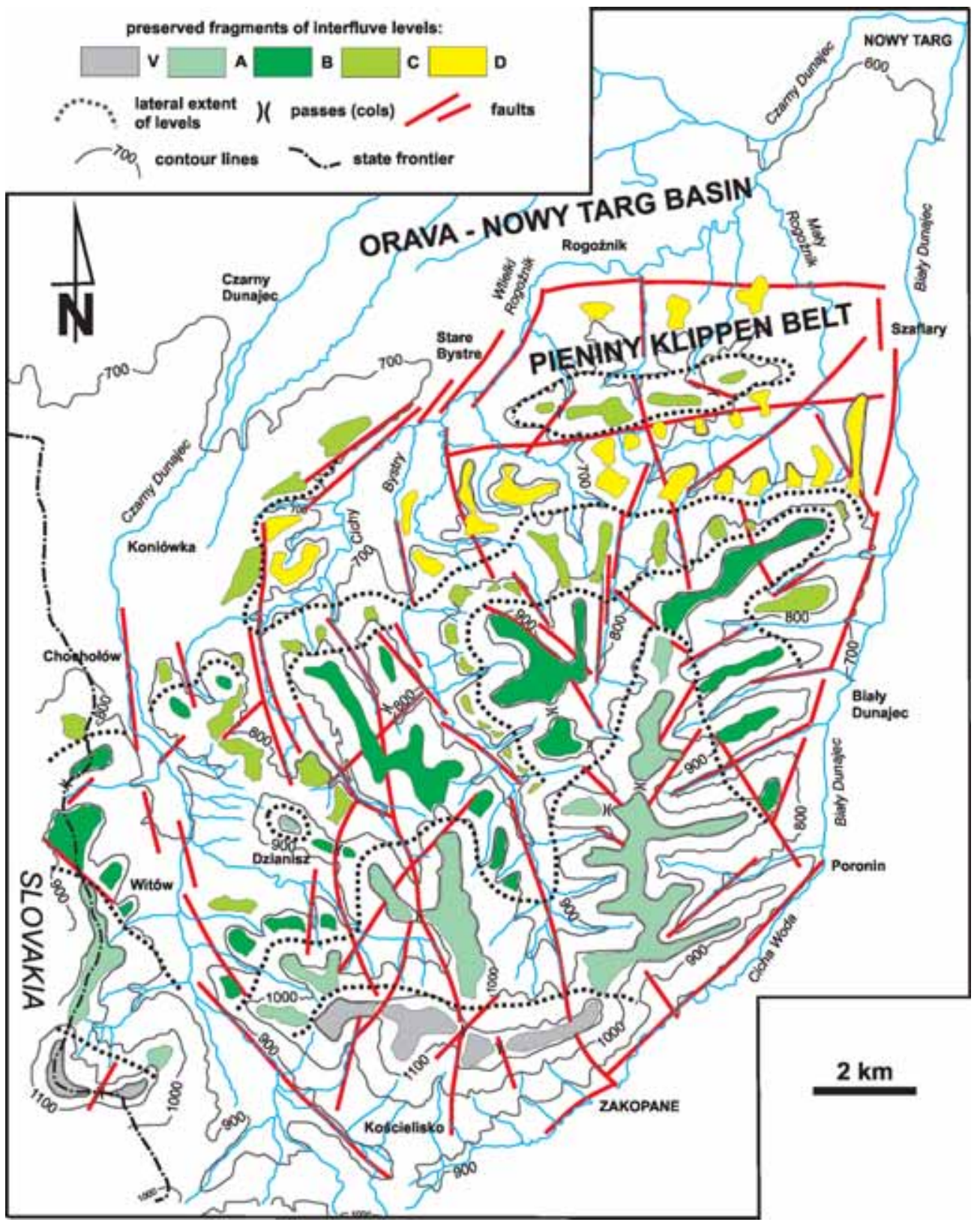

Figure 14. Staircase-like arrangement of interfluve levels in the western Podhale region (based on Kukulak, 1993; simplified). See Fig. 4 for location.

Nappe stacking proceeded continuously, although with variable intensity $(7.7-20 \mathrm{~mm} /$ yr), between Burdigalian and Serravallian (Oszczypko, 1997). As far as the Inner Car- pathians of Poland are concerned, the size of exhumation of the Tatra Mts. crystalline core, deduced from fission track determinations, amounted to $5 \mathrm{~km}$ during the past 


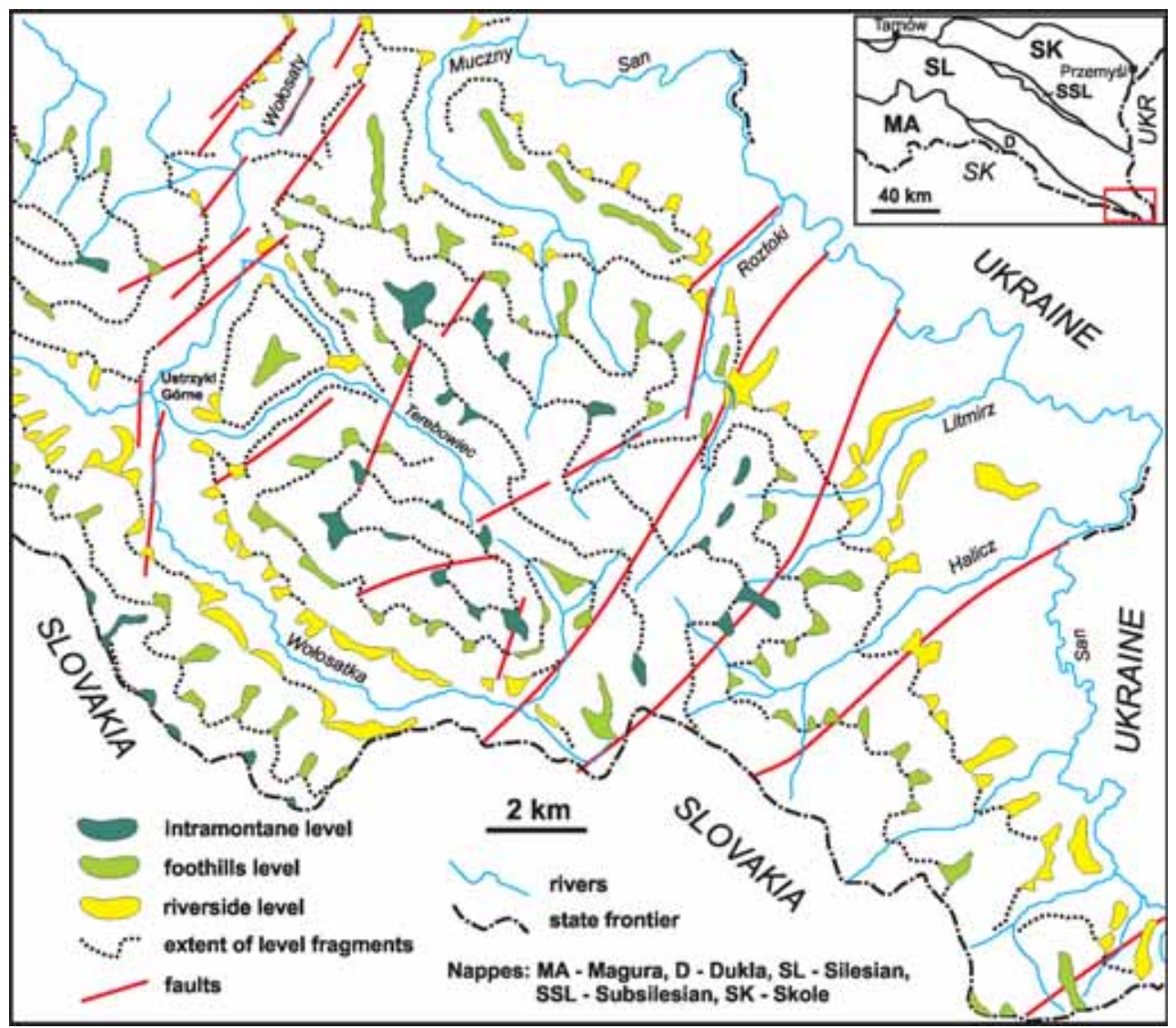

Figure 15. Remnants of planation surfaces in the Bieszczady Mts., Outer Eastern Carpathians of Poland (based on Kukulak, 2004; simplified). See Fig. 4 for location.

26-10 m.y. (Burchart, 1972) or 30-15 m.y. (Kovač et al., 1994), and to $2 \mathrm{~km}$ between 7 and 2 Ma (Baumgart-Kotarba and Král, 2002; cf. Fig. 16). Results of speleothem dating in the Tatra caves indicate that the age of the oldest denudation surfaces in the Tatra Mts. does not pre-date the youngest Miocene (Głazek, 1996). The reconstructed position of an hypothetical palaeo-summit surface in the Outer Eastern Carpathians of Poland was indicative of large, although differentiated values of denudation during exhumation (Kuśmierek, 1990; Maćkowski et al., 2009). One should also take into account the role of compaction of Miocene molasses underlying overthrust flysch nappes. These figures amounted to $500 \mathrm{~m}$ after the Early Sarmatian and 200-300 m after the Early Pliocene (Oszczypko et al., 1993). Rates of exhumation deduced from the size of erosional dissection of "planation surfaces" and variable estimates of Neogene denudation (Malarz, 1992; Zuchiewicz, 1995) are, therefore, poorly constrained. These circumstances led Minár (2003) to put forward a concept of the so-called „tectoplain”, i.e. polygenetic denudation-accumulational surface that originated due to planation of tectonically active areas in predominantly extensional regime. According to this view, the intramontane level should have developed diachronously following the last episode of nappe stacking in the OWC: strongly in the south and less strongly in the north, 


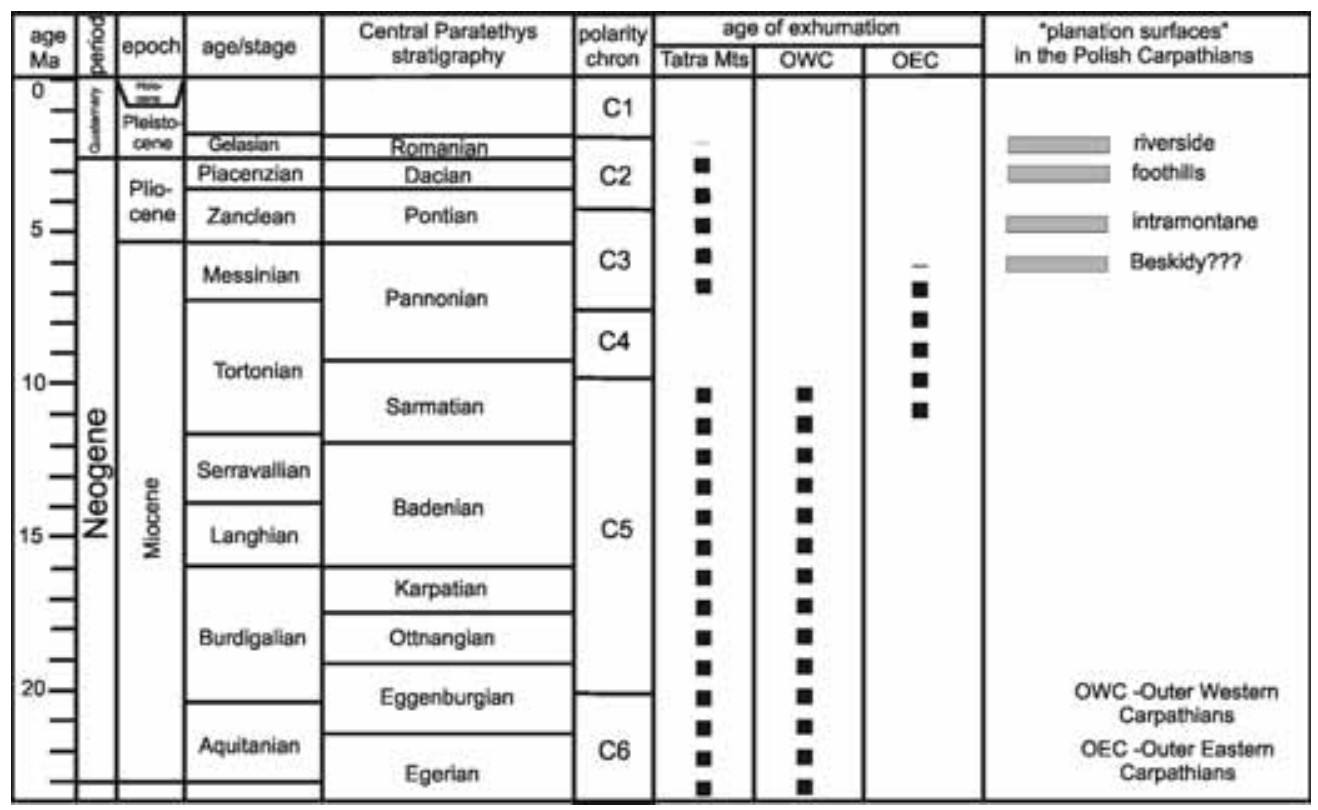

Figure 16. "Planation surfaces" in the Polish Carpathians versus the Late Cenozoic time scale and timing of exhumation inferred from apatite fission track dating

(compiled after Kováč et al., 1994, Baumgart-Kotarba and Král, 2002; Oszczypko et al., 2005;

Geological Time Scale, 2008; and Mazzoli et al., 2010).

and earlier (Pannonian) in the west and later (Pannonian-Pontian) in the east. The younger levels were to originate in the Pontian and Late Pliocene - Early Pleistocene times. The proposed time intervals resulted from field studies in the Bratislava environs and middle Hron River drainage basin, where the discussed denudation surfaces cut strata of well-constrained ages (Bizubová and Minár, 1992; Bizubová, 1998; Minár, 2003; Minár et al., 2004).

The size of exhumation of the medial segment of the OWC in Poland in Late Neogene and Quaternary times, inferred from relief energy values of "planation surfaces” (Starkel, 1972), used to be reconstructed at 150-900 m (av. $300 \mathrm{~m}$; cf. Zuchiewicz, 1984a,b, 1991). Nevertheless, the number and age of such surfaces are a matter of debate and the lack of correlative sediments prevents detailed age estimation. Recent attempts at fission track and (U-Th)/He dating of teschenite intrusions cut by the intra- montane level in the Czech segment of the OWC (Danišík et al., 2008) indicate that development of "planation surfaces” in this area must have post-dated the Pannonian (7.1 Ma), what does not contradict a concept of Pliocene age of these surfaces in the Polish Carpathians (Fig. 16; see also discussion in: Zuchiewicz, 1984a,b, 1995, 2010).

The estimated size of post-orogenic isostatic uplift during the past 10 m.y. changed between $1,000 \mathrm{~m}$ in the Western Beskidy Mts. to 260-360 $\mathrm{m}$ in the Carpathian Foothills (Oszczypko, 1996). Recently published estimates of the size of denudation based on analyses pertaining to the degree of diagenesis, fluid inclusions, or compaction of flysch strata (cf. Kuśmierek, 1990; Oszczypko et al., 1993; Kotulová et al., 1998; Hurai et al., 2000; Anczkiewicz et al., 2005; Świerczewska, 2005; Środoń et al., 2006; Środoń, 2008; Maćkowski et al., 2009) are a matter of debate. Moderate values of Bouguer gravity anomalies point to the role 
of non-isostatic processes leading to young uplift ranging between $250 \mathrm{~m}$ and $550 \mathrm{~m}$ (Zoetemeijer et al., 1999). A more reliable estimate is provided by fission track studies (cf. Mazzoli et al., 2010). These data indicate that exhumation $(32.1 \pm 4.8$ to $7.0 \pm 0.8 \mathrm{Ma})$ was in part coeval with tectonic shortening, relatively fast, and ,younging” towards the east. The average rate of exhumation (0.6 to $0.8 \mathrm{~mm}$ per year, depending on the assumed value of geothermal gradient) largely exceeded the reconstructed rates of erosion, pointing to dominant role played by extension-related tectonic exhumation (Mazzoli et al., 2010).

\section{CONCLUSIONS}

Infrequent fission track dating pertaining to the age of exhumation of the Carpathian orogen indicate that the preserved "planation surfaces" (intramontane, foothills, riverside) could not had formed before ca. 7 Ma. A possibility exists, however, that individual bevels could have been shaped at the same time at different altitudes, with respect to local base levels and differentiated bedrock resistance to erosion.

\section{ACKNOWLEDGEMENTS}

This study was financially supported through the AGH University of Science and Technology statutory funds (no. 11.11.140.560).

\section{REFERENCES}

Adams, G. (ed.) (1975), Planation Surfaces, Benchmark Papers in Geology, 22, Stroudsburg, PA, Dowden, Hutchinson and Ross, 1-476.

Allen, Ph. A. (2008), Time scales of tectonic landscapes and their sediment routing systems, in Gallagher, K., Jones, S. J. and Wainwright, J. (eds.), Landscape Evolution: Denudation, Climate and Tectonics over Different Time and Space Scales, Geological Society, London, Special Publications, 296: 7-28.
Anczkiewicz, A.A., Zattin, M. and Środoń, J. (2005), Cenozoic uplift of the Tatras and Podhale basin from the perspective of the apatite fission track analyses, Polskie Towarzystwo Mineralogiczne-Prace Specjalne, 25: 261-264.

Babault, J., Bonnet, S., Van Den Driessche, J. and Crave, A. (2007), High elevation of low-relief surfaces in mountain belts: does it equate to post-orogenic surface uplift? Terra Nova, 19: 272-277.

Bac-Moszaszwili, M. (1993), Struktura zachodniego zakończenia masywu tatrzańskiego [Structure of the western termination of the Tatra massif], Annales Societatis Geologorum Poloniae, 63: 167-193.

Bac-Moszaszwili, M. (1995), Diversity of Neogene and Quaternary tectonic movements in the Tatra Mountains, Folia Quaternaria, 66: 131-144.

Bashenina, N. V., Mirnova, A. V. and Talskaya, N. N. (1969), Block tectonics of the Carpathians and its reflection in the relief, Studia Geomorphologica Carpatho-Balcanica, 3: 45-60.

Baumgart-Kotarba, M. (1973), Polycyclic mountain ridges in the Flysch Carpathians, Studia Geomorphologica Carpatho-Balcanica, 7: 41-51.

Baumgart-Kotarba, M. (1974), Rozwój grzbietów górskich w Karpatach fliszowych [Development of mountain ridges in the flysch Carpathians], Prace Geograficzne 106, Instytut Geografii i Przestrzennego Zagospodarowania (IGiPZ) PAN: 1-133.

Baumgart-Kotarba, M. (1983), Kształtowanie koryt i teras rzecznych w warunkach zróżnicowanych ruchów tektonicznych (na przykładzie wschodniego Podhala) [Channel and terrace formation due to differential tectonic movements (with the eastern Podhale Basin as example)], Prace Geograficzne 145, Instytut Geografii i Przestrzennego Zagospodarowania (IGiPZ) PAN: 1-145.

Baumgart-Kotarba, M. (1996), On origin and age of the Orawa Basin, West Carpathians, Studia Geomorphologica Carpatho-Balcanica, 30: 101-116.

Baumgart-Kotarba, M., Gilewska, S. and Starkel, L. (1976), Planation surfaces in the light of the 1: 300,000 geomorphological map of Poland, Geographia Polonica, 33: 5-22. 
Baumgart-Kotarba, M. and Král, J. (2002), Young tectonic uplift of the Tatra Mts. (fission track data and geomorphological arguments), in Michalik, J., Šimon, L. and Vozár, J. (eds.), Proceedings of the XVII Congress of Carpathian-Balkan Geological Association, Bratislava, 1st-4th Sept. 2002, Geologica Carpathica, 53, Special Issue, CD-Rom, 4 pp. (not paginated).

Bąk, K. (1989), W sprawie poziomów zrównań w dorzeczu Białki, w Tatrach Wysokich [In the case of planation surfaces in the Białka drainage in the High Tatra Mountains], Folia Geographica, series geographica-physica, 21: 93-115.

Bíl, M., Krejčí, O., Franců, J., Hrouda, F. and Přichystal, A. (2004), Estimation of the missing eroded sediments in the Bílé Karpaty Unit (Outer West Carpathians), Studia Geomorphologica Carpatho-Balcanica, 38: 59-66.

Bizubová, M. (1998), Časovo-priestorové zmeny Západných Karpat v neogéne a denudačná chronológia [Temporal-spatial changes of the Western Carpathians in the Neogene and denudational chronology], Acta Facultatis Studiorum Humanitatis et Naturae Universitatis Prešoviensis, Prírodné vedy, Folia Geographica, 2: 290-297.

Bizubová, M. and Minár, J. (1992), Some new aspects of denudation chronology of West Carpathians, in Stankoviansky, M., (ed.), Abstracts of Papers, International Symposium "Time, Frequency and Dating in Geomorphology”, Tatranská Lomnica - Stará Lesná, June 16-21, 1992, Bratislava.

Brud, S. (2004), Palaeogeography of the western Sandomierz Basin in Late Neogene and Early Quaternary times (Carpathian Foredeep, South Poland), Annales Societatis Geologorum Poloniae, 74: 63-93.

Brud, S. and Worobiec, G. (2003), Wyniki badań makroszczątków roślin $\mathrm{z}$ serii witowskiej (południowa Polska) [Results of investigations on plant macroremains found in deposits of the Witów Series (southern Poland)], Przegląd Geologiczny, 51 (5): 392-401.

Burchart, J. (1972), Fission-track age determinations of accessory apatite from the Tatra Mts., Poland, Earth and Planetary Science Letters, 15: 418-422.
Calvet, M. and Gunnell, Y. (2008), Planar landforms as markers of denudation chronology: an inversion of East Pyrenean tectonics based on landscape and sedimentary basin analysis, in Gallagher, K., Jones, J. and Wainwright, J. (eds.), Landscape Evolution: Denudation, Climate and Tectonics over Different Time and Space Scales, Geological Society, London, Special Publications, 296: 147-166.

Cieszkowski, M., Witek, K. and Wójcik A. (1977), Nowe stanowisko osadów miocenu koło Dubiecka [New locality of the Miocene from the vicinities of Dubiecko], Przeglad Geologiczny, 25 (7): 363-366.

Cisek, B. and Czernicki, J. (1964), Budowa geologiczna i rozwój facjalny miocenu strefy zewnętrznej przedgórza Karpat środkowych (in Polish), Geofizyka i Geologia Naftowa, 8-9.

Clark, M. K., Maheo, G., Saleeby, J. and Farley, K. A. (2005), The non-equilibrium landscape of the southern Sierra Nevada, California, GSA Today, 15: 4-10.

Činčura, J. (1967), Ein Beitrag zum Alter des Flussniveaus in den Westkarpaten, Geografický Časopis, 19 (4): 316-326.

Daníšík, M., Pánek, T., Matýsek, D., Dunkl, I. and Frisch, W. (2008), Apatite fission track and (U-Th)/He dating of teschenite intrusions gives time constraints on accretionary processes and development of planation surfaces in the Outer Western Carpathians, Zeitschrift für Geomorphologie, Neue Folge, 52: 273-289.

Davis, W. M. (1911), The Colorado Front range, a study on physiographic presentation, Annals of the Association of American Geographers, 1: 21-83.

Demediuk, N. S. (1983), Poverkhnosti vyravnivania Ukrainskikh Karpat i ikh predgorii [Planation surfaces in the Ukrainian Carpathians and in their promontories], Studia Geomorphologica Carpatho-Balcanica, 16: 3-14.

Demediuk, M. S. (1994), Morfostruktury i morfoskulptury teritorii karpatskogo geodinamichnogo poligonu [Morphostructures and morphosculptures of the Carpathian geodynamic test area], in Ostrovskiy, A. (ed.), Mizhnarodnyi sympozium "Geodinamika girskikh sistem Evropy” (tezy dopovidey), Lviv - Yaremche 
10-17 IV 1994 r., Lviv, Golovnoe upravlenie geodezii, kartografii ta kadastru Ukrainy, 17, [in Ukrainian].

Dżułyński, S., Krysowska-Iwaszkiewicz, M., Oszast, J. and Starkel, L. (1968), O staroczwartorzędowych żwirach w Kotlinie Sandomierskiej [On Lower Quaternary gravels in the Sandomierz Basin], Studia Geomorphologica Carpatho-Balcanica, 2: 63-75.

Fairbridge, R. W. and Finkl, C. W. (1980), Cratonic erosional unconformities and peneplains, Journal of Geology, 88: 69-86.

Fleszar, A. (1914), Próba morfogenezy Karpat położonych na północ od Krosna [Morphogenesis of the Carpathians situated north of Krosno], Kosmos, 39: 99-121, [in Polish, French summary].

Fodor, L., Csontos, L., Bada, G., Györfi, I. and Benkovics, L. (1999), Tertiary tectonic evolution of the Pannonian Basin system and neighbouring orogens: a new synthesis of palaeostress data, in Durand, B., Jolivet, L., Horvath, F. and Seranne, M. (eds.), The Mediterranean Basins: Tertiary Extension within the Alpine Orogen, Geological Society, London, Special Publications, 156: 295-334.

Fusan, O., Ibrmajer, J. and Plančar, J. (1979), Neotectonic blocks of the West Carpathians, in V. Babuška, V. and Plančar, J. (eds.), Geodynamic investigations in Czechoslovakia, Bratislava, VEDA, 187-192.

Geological Time Scale (2008), International Commission on Stratigraphy.

Gilewska, S. (1987), The Tertiary environment in Poland, Geographia Polonica, 53: 19-41.

Głazek, J. (1996), Kras i jaskinie Tatr Polskich, stan i perspektywy badań [Karst and caves of the Polish Tatra Mountains, state of knowledge and perspectives], in Kotarba, A. (ed.), Przyroda Tatrzańskiego Parku Narodowego a czlowiek [The Nature of the Tatra National Park and Man], Vol. 1, Nauki o Ziemi, Tatrzański Park Narodowy, Polskie Towarzystwo Przyjaciół Nauk o Ziemi Oddział w Krakowie, Kraków - Zakopane, 31-44.

Golonka, J., Pietsch, K., Marzec, P., Stefaniuk, M., Waśkowska, A. and Cieszkowski, M. (2009), Tectonics of the western part of the Polish Outer Carpathians, Geodinamica Acta, 22: 127-143.
Gubbels, T. L., Isacs, B. L. and Farrar, E. (1993), High-level surfaces, plateau uplift, and foreland development, Bolivian Central Andes, Geology, 21: 695-698.

Haczewski, G., Kukulak, J. and Bąk, K. (2007), Budowa geologiczna i rzeźba Bieszczadzkiego Parku Narodowego [Geology and relief of the Bieszczady National Park], Prace Monograficzne Akademii Pedagogicznej im. Komisji Edukacji Narodowej w Krakowie, 468: 1-155.

Harčár, J. (1975), Anteil der Tektonik und der Quartär-geologischen und morphologischen Entwicklung des Hron-Hügellandes und des Žitava-tales, Geografický Časopis, 27: 25-29.

Henkiel, A. (1969), Ewolucja morfologiczna dorzecza Strwiąża [Morphologic evolution of the drainage basin of the Strwiąż river], $A n$ nales UMCS, Section B, 24 (4): 99-140.

Henkiel, A. (1977), Zależność rzeźby Karpat Zewnętrznych od budowy geologicznej jednostek fliszowych i ich głębokiego podłoża (na przykładzie wschodniej części Karpat polskich) [Morphology of the Outer Carpathians versus geological structure of flysch units and their deep basement; on the example of the eastern portion of the Polish Carpathians], Rozprawy habilitacyjne UMCS, Lublin, Wydawnictwo UMCS, 1-100, [in Polish].

Henkiel, A. (1977-78), O pochodzeniu rzeźby polskich Karpat fliszowych [The origin of the relief of the Polish Flysch Carpathians], $A n$ nales UMCS, Section B, 32-33 (1): 1-35.

Hurai, V., Świerczewska, A., Marko, F., Tokarski, A. K. and Hrušecký, I. (2000), Paleofluid temperatures and pressures in Tertiary accretionary prism of the Western Carpathians, Slovak Geological Magazine, 6: 194-197.

Jiŕíček, R. (1979), Tectogenetic development of the Carpathian arc in the Oligocene and Neogene, in Mahel, M. (ed.), Tectonic Profiles through the West Carpathians, Bratislava, Geologický Ústav D. Štura, 205-214.

Klimaszewski, M. (1934), Z morfogenezy Polskich Karpat Zachodnich [Morphogenesis of the Polish Western Carpathians], Wiadomości Geograficzne, 12 (5-9): 30-41, [in Polish, French summary].

Klimaszewski, M. (1937), Morfologia i dyluwium doliny Dunajca od Pienin po ujście [Morphologie und Diluvium des Dunajec-Tales von den 
Pieninen bis zur Mündung], Prace Instytutu Geograficznego UJ, 18: 1-54.

Klimaszewski, M. (1965), Dévéloppement géomorphologique des Carpathes Occidentales polonaises, Geographia Polonica, 9: 15-32.

Klimaszewski, M. (1966), Views on the geomorphological development of the Polish Western Carpathians during the Quaternary, in: Geomorphological Problems of Carpathians, Vol. 2, Warszawa, Wydawnictwo Naukowe PWN, 51-88.

Klimaszewski, M. (1967), Polskie Karpaty Zachodnie w okresie czwartorzędowym [Polish Western Carpathians in Quaternary period], in Galon, R. and Dylik, J. (eds.), Czwartorzęd Polski [Quaternary of Poland], Warszawa, Wydawnictwo Naukowe PWN, 431-497, [in Polish].

Klimaszewski, M. (1987), O rozwoju geomorfologicznym Karpat Zachodnich [Geomorphic development of the Western Carpathians], Przeglad Geograficzny, 59: 405-419 [in Polish].

Klimaszewski, M. (1988), Rzeźba Tatr polskich [Morphology of the Polish Tatra Mountains], Warszawa, Wydawnictwo Naukowe PWN, 1-668, [in Polish].

Kotulová, J., Biroň, A. and Soták, J. (1998), Organic and illite-smectite diagenesis of the Central Carpathian Paleogene basin: implications for thermal history, Abstracts, XVI Congress, Carpatho-Balkan Geological Association, Vienna, 30 Aug. - 2 Sept., 1998, 293.

Kováč, M. (2000), Geodynamický, paleogeografický a štruktúrny vývoj karpatsko-panónskeho regiónu $\mathrm{v}$ miocéne: nový pohl'ad na neogénne panvy Slovenska [Geodynamic, palaeogeographic and structural development of the Carpathian-Pannonian area in the Miocene: a new view on the Neogene basins in Slovakia], Bratislava, VEDA, Vydavatelstvo Slovenskej Akademie Vied, 1-202, [in Slovak].

Kováč, M., Andreyeva-Grigorovich, A., Bajraktarević, Z., Brzobohatý, R., Filipescu, S., Fodor, L., Harzhauser, M., Nagymarosy, A., Oszczypko, N., Pavelić, D., Rögl, F., Saftić, B., Sliva, L. and Studencka, B. (2007), Badenian evolution of the Central Paratethys Sea: paleogeography, climate and eustatic sea-level changes, Geologica Carpathica, 58: 579-606.

Kováč, M., Král, J., Márton, E., Plašienka, D. and Uher, P. (1994), Alpine uplift history of the Central Western Carpathians: geochronological, paleomagnetic, sedimentary and structural data, Geologica Carpathica, 45: 83-96.

Krawczyk, A. and Zuchiewicz, W. (1989), Regionalna zmienność parametrów fizjograficznych zlewni i ich związek z budową geologiczną dorzecza Dunajca, polskie Karpaty Zachodnie [Regional variability of physiographic parameters of catchment areas and their relation to geological structure of the Dunajec drainage basin, Polish West Carpathians], Zeszyty Naukowe AGH, Geologia, 14 (3): 5-38.

Książkiewicz, M. (1972), Karpaty [The Carpathians], in Pożaryski, W. (ed.), Budowa geologiczna Polski [Geological structure of Poland], Vol. 4, Part 3, Tektonika, Warszawa, Wydawnictwa Geologiczne, 1-228.

Kukulak, J. (1991), Udział tektoniki w rozwoju poziomów grzbietowych Zachodniego Podhala [Influence of tectonics on ridge levels development in the Western Podhale], Folia Geographica, series geographica-physica, 22: 87-102.

Kukulak, J. (1993), Przejawy aktywności ruchów pionowych w rzeźbie zachodniego Podhala [The reflection of vertical crustal movements in morphology of the Western Podhale region, South Poland], Folia Quaternaria, 64: 151-164.

Kukulak, J. (2004), Neotectonics and planation surfaces in the High Bieszczady Mountains (Outer Carpathians, Poland), Annales Societatis Geologorum Poloniae, 74: 339-350.

Kuśmierek, J. (1990), Zarys geodynamiki centralnokarpackiego basenu naftowego [Outline of geodynamics of Central Carpathian oil basin], Prace Geologiczne Komisji Nauk Geologicznych PAN, Oddziat w Krakowie, 135: 1-85.

Kvaček, Z., Kováč, M., Kovar-Eder, J., Doláková, N., Jechorek, H., Parashiv, V., Kováčová, M. and Sliva, L. (2006), Miocene evolution of landscape and vegetation in the Central Parathethys, Geologica Carpathica, 57: 295-310.

Lacika, J. (2004), Neotectonic evolution of the West Carpathian drainage basins in Slovakia, Studia Geomorphologica Carpatho-Balcanica, 38: 23-47. 
Lacika, J. and Urbánek, J. (1998), Morphostructures of the West Carpathians of Slovakia, Studia Geomorphologica Carpatho-Balcanica, 32: 60-67.

Lukniš, M. (1962), Die Reliefentwicklung der Westkarpaten, Wissenschaftliche Zeitschrift der Martin-Luther-Universität Halle-Wittenberg, Mathematik-Naturwissenschaften, 11 (10): 1235-1244.

Lukniš, M. (1964), Pozostatky po staršich povrchov zarovnávania reliéfu v československých Karpatoch [Remnants of old planation surfaces in the Czechoslovak Carpathians], Geografický Časopis, 16 (3): 289-298, [in Slovak, German summary].

Łańcucka-Środoniowa, M. (1963), Stan badań paleobotanicznych nad miocenem Polski poludniowej [Palaeobotanical investigations on the Miocene of southern Poland], Rocznik Polskiego Towarzystwa Geologicznego, 33: 129-158.

Łańcucka-Środoniowa, M. (1979), Macroscopic plant remains from the freshwater Miocene of the Nowy Sącz Basin (West Carpathians, Poland), Acta Palaeobotanica, 20 (1): 3-117.

Łój, M., Madej, J., Porzucek, S. and Zuchiewicz, W. (2009), Monitoring geodynamic processes using geodetic and gravimetric methods: An example from the Western Carpathians (South Poland), Kwartalnik AGH, Geologia, 35 (2): 217-247.

Maćkowski, T., Kuśmierek, J., Reicher, B., Baran, U., Kosakowski, P., Łapinkiewicz, A. P., Machowski, G., Papiernik, B., Szczygieł, M., Zając, A. and Zych, I. (2009), Dwuwymiarowe modele termicznego przeobrażenia materii organicznej i ekspulsji węglowodorów w transgranicznej strefie Karpat polsko-ukraińskich [Two-dimensional models of the organic-matter thermal transformation and hydrocarbon expulsion in the transfrontier zone of the Polish and Ukrainian Carpathians], Kwartalnik AGH, Geologia, 35 (4/1): 191-222.

Malarz, R. (1974), Próba określenia wieku beskidzkiej powierzchni zrównania [An attempt to define the age of the Beskidy planation surface], Rocznik Naukowo-Dydaktyczny WSP w Krakowie, 55, Prace Geograficzne, 6: 93-100.

Malarz, R. (1992), Etap denudacyjny w polskich Karpatach fliszowych [Denudational stage in the Polish Flysch Carpathians], Prace Monograficzne WSP w Krakowie, 150: 1-158 [in Polish].

Malarz, R. and Ziętara, T. (1975), On the age of the Beskid planation surface in the Western Beskidy Mountains, Studia Geomorphologica Carpatho-Balcanica, 9: 125-133.

Mazúr, E. (1963), Žilinska Kotlina a prilahle pohoria (geomorfologia a kvarter) [The Žilina Basin and the adjacent mountains (geomorphology and Quaternary era)], Bratislava, Vydavatelstvo Slovenskej Akademie Vied, $1-186$.

Mazúr, E. (1965), Major features of the West Carpathians in Slovakia as a result of young tectonic movements, in Mazúr, E. and Stehlik, O. (eds.), Geomorphological Problems of Carpathians, 1, Bratislava, Vydavatelstvo Slovenskej Akademie Vied, 9-53.

Mazúr, E. (1979), Morfoštruktúry Zapadných Karpát a ich vyvoj [Morphostructures of the Western Carpathians and their development], Acta Facultatis Rerum Naturalium Universitatis Comenianae, Geographia, 17: 21-34.

Mazúr, E. and Činčura, J. (1975), Poverkhnosti vyravnivaniya Zapadnykh Karpat [Planation surfaces in the Western Carpathians], Studia Geomorphologica Carpatho-Balcanica, 9: 27-36.

Mazzoli, S., Jankowski, L., Szaniawski, R. and Zattin, M. (2010), Low-T thermochronometric evidence for post-thrusting $(<11 \mathrm{Ma})$ exhumation in the Western Outer Carpathians, Poland, Comptes Rendus Geoscience, doi: 10.1016/j.crte.2009.11.001

Migoń, P. (2004a), Peneplain, in Goudie, A. S. (ed.), Encyclopedia of Geomorphology, Vol. 2, London, Routledge, 771-772.

Migoń, P. (2004b), Planation surface, in: Encyclopedia of Geomorphology, Vol. 2, London, Routledge, 788-792.

Minár, J. (2003), Stredohorská roveň v Západných Karpatoch ako tektoplén: náčrt pracovnej hypotézy [Intramontane planation surface in the Western Carpathians as a tectoplain: an outline of a working hypothesis], Geografický Časopis, 55: 141-158.

Minár, J., Bizubová, M. and Gallay, M. (2004), General aspects of denudation chronology of the West Carpathians, Studia Geomorphologica Carpatho-Balcanica, 38: 5-22. 
Mojski, J. E. (2005), Ziemie polskie w czwartorzedzie. Zarys morfogenezy [Poland in Quaternary times. An outline of morphogenesis], Państwowy Instytut Geologiczny, Warszawa, 1-404, [in Polish].

Neubauer, F., Cloetingh, S., Dinu, C., and Mocanu, V. (1997), Tectonics of the Alpine-Carpathian-Pannonian region: introduction, $\mathrm{Tec}$ tonophysics, 272: 93-96.

Oberlander, T. M. (1989), Slope and pediment systems, in Thomas, D. S. G. (ed.), Arid Zone Geomorphology, London, Belhaven, 56-84.

Obuchowicz, Z. (1963), Budowa geologiczna przedgórza Karpat Środkowych [Geological structure of the Carpathian foreland], Prace Instytutu Geologicznego, 30: 321-350.

Oszast, J. and Stuchlik, L. (1977), Roślinność Podhala w neogenie [The Neogene vegetation of the Podhale (West Carpathians, Poland)], Acta Palaeobotanica, 18 (1): 45-86.

Oszczypko, N. (1996), Mioceńska dynamika polskiej części zapadliska przedkarpackiego [The Miocene dynamics of the Carpathian Foredeep in Poland], Przeglad Geologiczny, 44 (10): 1007-1018.

Oszczypko, N. (1997), The Early-Middle Miocene Carpathian peripheral foreland basin (Western Carpathians, Poland), Przeglad Geologiczny, 45: 1054-1063.

Oszczypko, N., Krzywiec, P., Popadyuk, I. and Peryt, T. (2005), Carpathian Foredeep Basin (Poland and Ukraine): Its Sedimentary, Structural, and Geodynamic Evolution, in Golonka, J. and Picha, F. (eds), The Carpathians and their Foreland: Geology and Hydrocarbon Resources, American Association of Petroleum Geologists Memoir, 84: 261-318.

Oszczypko, N. and Ślączka, A. (1985), An attempt to palinspastic reconstruction of Neogene basins in the Carpathian Foredeep, Annales Societatis Geologorum Poloniae, 55: 55-75.

Oszczypko, N., Ślączka, A. and Żytko, K. (2008), Regionalizacja tektoniczna Polski - Karpaty zewnętrzne i zapadlisko przedkarpackie [Tectonic subdivision of Poland: Polish Outer Carpathians and their foredeep], Przeglad Geologiczny, 56: 927-935.

Oszczypko, N., Tomaś, A. and Zuchiewicz, W. (1993), Rola kompakcji w ocenie mobilności neotektonicznej pogórzy karpackich [Com- paction of Miocene molasses and neotectonic mobility of the Polish Carpathian Foothills], Przeglad Geologiczny, 41: 411-416.

Pawłowski, S. (1916), W sprawie wieku nowszej rzeźby polskich Karpat fliszowych [To the age of younger relief of the Polish Flysch Carpathians], Sprawozdania Komisji Fizjograficznej AU, 50: 1-12 [in Polish, German summary].

Pécsi, M. (1994), Landform evolution model of alternating erosional-accumulational geomorphic surfaces, in: Abstracts, Visegrad, Carpatho-Balkan Geomorphological Commission, 17-18.

Pécsi, M., Scheuer, G., Schweitzer, F., Hahn, G. and Pevzner, M. (1985), Neogene-Quaternary geomorphological surfaces in the Hungarian Mountains, in Kretzoi, M. and Pécsi, M. (eds), Problems of the Neogene and Quaternary, Budapest, Akademiai Kiado, 51-63.

Pelletier, J. D. (2010), How do pediments form? A numerical modeling investigation with comparison to pediments in southern Arizona, USA, Bulletin of the Geological Society of America, 122: 1815-1829.

Phillips, J. D. (2002), Erosion, isostatic response, and the missing peneplains, Geomorphology, 45: 225-241.

Pokorny, W. (1911), Przyczynek do dawnej penepleny karpackiej w okolicach Chyrowa [A contribution to the former Carpathian peneplain near Chyrów], Kosmos, 36: 549-558, [in Polish, German summary].

Połtowicz, S. (1974), Wgłębna tektonika brzegu Karpat w okolicy Tarnowa i Pilzna [Tectonic structures of the Carpathian border in the Tarnów and Pilzno area (Polish Middle Carpathians)], Rocznik Polskiego Towarzystwa Geologicznego, 44: 491-514.

Połtowicz, S. and Starczewska-Popow, A. (1973), Rozwój Zapadliska Przedkarpackiego między Tarnowem a Przemyślem [The development of the Carpathian Foredeep between Tarnów and Przemyśl, Polish Eastern Carpathians], Rocznik Polskiego Towarzystwa Geologicznego, 43: 495-518.

Pomianowski, P. (2003), Tektonika Kotliny Orawsko-Nowotarskiej - wyniki kompleksowej analizy danych grawimetrycznych i geoelektrycznych [Tectonics of the Orava 
- Nowy Targ Basin - results of the combined analysis of the gravity and geoelectrical data], Przeglad Geologiczny, 51 (6): 498-506.

Rajchel, J. (1976), Budowa geologiczna nowych płatów miocenu okolic Dubiecka (Karpaty Przemyskie) [Geological structure of the newly-discovered Miocene exposures near Dubiecko], Sprawozdania z Posiedzeń Komisji Naukowych PAN, Oddziat w Krakowie, 19 (1): 156-158, [in Polish].

Romer, E. (1907), Zur Geschichte des Dniestrtales, Mitteilungen der k.k. geographische Gesellschaft Wien: 275-292.

Rudnytsky, S. (1905), Znadoby do morfologii karpatskoho stochishcha Dnistra [A contribution to the morphology of the Carpathian part of the Dnister River basin], Zbirnyk matematichno-prirodopisno-likars'koy sektsii Naukovogo tovaristva imeni Shevchenka, 10: 1-85, [in Ukrainian].

Sawicki, L. (1909), O młodszych ruchach górotwórczych w Karpatach [The younger orogenic movements in the Carpathians], Kosmos, 34 (5-6): 361-400, [in Polish, German summary].

Smoleński, J. (1911), Z morfogenezy Beskidu Niskiego [To the morphogenesis of the Beskid Niski Mountains], in: Księga Pamiatkowa XI Zjazdu Lekarzy i Przyrodników Polskich (18-22 VII 1911) [Proceedings of the 11th Congress of the Polish Physicians and Naturalists, 18-22 Jul. 1911], Kraków, 232-234, [in Polish].

Smoleński, J. (1937), W sprawie wieku i genezy krajobrazu Beskidów Zachodnich [To the age and origin of the Western Beskidy Mts. landscape], Wiadomości Geograficzne, 15 (3-4): 59-74, [in Polish, German summary].

Starkel, L. (1957), Rozwój morfologiczny progu Pogórza Karpackiego między Dębicą a Trzcianą [Morphological development of the escarpment of the Pogórze Karpackie between Dębica and Trzciana], Prace Geograficzne, 11, Instytut Geografii i Przestrzennego Zagospodarowania (IGiPZ) PAN: 1-154.

Starkel, L. (1965), Rozwój rzeźby polskiej części Karpat Wschodnich (na przykładzie dorzecza górnego Sanu) [Geomorphological development of the Polish Eastern Carpathians (upon the example of the Upper San basin)],
Prace Geograficzne 50, Instytut Geografii i Przestrzennego Zagospodarowania (IGiPZ) PAN: 1-160.

Starkel, L. (1966), Evolution of the relief of the Polish East Carpathians in the Quaternary (with the Upper San basin as example), in: Geomorphological Problems of Carpathians, Vol. 2, Warszawa, Wydawnictwo Naukowe PWN, 89-114.

Starkel, L. (1969a), Climatic or tectonic adaptation of the relief of young mountains in the Quaternary, Geographia Polonica, 17: 209-229.

Starkel, L. (1969b), The age of the stages of development of the relief of the Polish Carpathians in the light of the most recent geological investigations, Studia Geomorphologica Carpatho-Balcanica, 3: 33-44.

Starkel, L. (1972), Karpaty Zewnętrzne [The Outer Carpathians], in Klimaszewski, M. (ed.), Geomorfologia Polski [Geomorphology of Poland], Vol. 1, Warszawa, Wydawnictwo Naukowe PWN, 52-115, [in Polish].

Starkel, L. (1975), Soobshchenie o sovremennom sostoyanii issledovanii razvitia poverkhnostei vyravnivaniya v polskikh Karpatakh [A short note about recent state of studies of the development of planation surfaces in the Polish Carpathians], Studia Geomorphologica Carpatho-Balcanica, 9: 75-81, [in Polish, French summary].

Starkel, L. (1976), Zagadnienie młodych ruchów tektonicznych w świetle przeglądowej mapy geomorfologicznej Polski [Young tectonic movements in the light of the synoptic geomorphological map of Poland], Materiaty I Krajowego Sympozjum "Wspótczesne $i$ neotektoniczne ruchy skorupy ziemskiej w Polsce" [Proceedings of the 1st National Symposium "Recent and neotectonic crustal movements in Poland"], II, Warszawa, Wydawnictwa Geologiczne, 127-133.

Starkel, L. (1988), O genezie i wieku zrównań w polskich Karpatach (w odpowiedzi Profesorowi M. Klimaszewskiemu) [The origin and age of planation surfaces in the Polish Carpathians (reply to Prof. M. Klimaszewski)], Przeglad Geograficzny, 60: 401-408, [in Polish].

Starkel, L. (1991), Rzeźba terenu [Relief], in Dynowska, I. and Maciejewski, M. (eds.), Dorzecze górnej Wisty [The Upper Vistula 
River drainage basin], part I, WarszawaKraków, Wydawnictwo Naukowe PWN, 4254, [in Polish].

Starkel, L. (2003), Are the planation surfaces still existing in the flysch Carpathians? Geomorphologia Slovaca, 3 (1): 73.

Stehlik, O. (1964), Přispevek k poznani tektoniky Beskydskeho horskeho oblouku [A contribution to the tectonics of the Beskidy mountain block], Geografický Časopis, 16: 271-280.

Stehlik, O. (1965), The Beskydy Mts. Arc, in: Geomorphological Problems of Carpathians, Vol. 1, Bratislava, VEDA, 71-80.

Stuchlik, L. (1980), Chronostratygrafia neogenu Polski południowej (północna część Paratetydy Centralnej) na podstawie badań paleobotanicznych [Chronostratigraphy of the Neogene in Southern Poland (northern part of the Central Paratethys) on the basis of palaeobotanical studies], Przegląd Geologiczny, 28 (8): 443-448.

Środoń, J. (2008), Diagenetic history of the Podhale flysch basin, Geoturystyka, 2 (13): 45-50.

Środoń, J., Kotarba, M., Biroň, A., Such, P., Claver, N. and Wójtowicz, A. (2006), Diagenetic history of the Podhale - Orava Basin and the underlying Tatra sedimentary structural units (Western Carpathians): evidence from XRD and K-Ar of illite-smectite, Clay Minerals, 41: 751-774.

Świderski, B. (1934-35), Zarys morfologji polskich Karpat fliszowych [Aperçu sur la morphologie des Karpates du flysch] [An outline of morphology of the Polish Flysch Carpathians], Przeglad Geograficzny, 14 (1-2): 1-40 [in Polish, French summary].

Świerczewska, A. (2005), The interplay of the thermal and structural histories of the Magura Nappe (Outer Carpathians) in Poland and Slovakia, Mineralogia Polonica, 36 (2): 91-144.

Teisseyre, H. (1928), Powierzchnia szczytowa Karpat [The summit surface of the Carpathians], Prace Geograficzne E. Romera, 10: 67112, Lwów, [in Polish, French summary].

Teisseyre, W. (1921), O stosunku wewnętrznych brzegów zapadlin przedkarpackich do krawędzi fliszu karpackiego [On the relationship between inner margins of the Fore-Carpathian basins to the border of the Carpathian flysch], Sprawozdania Państwowego Instytutu Geologicznego, 1 (2-3): 103-138, [in Polish, French summary].

Tokarski, A. K. (1975), Geologia i geomorfologia okolic Ustrzyk Górnych (polskie Karpaty Wschodnie) [Geology and geomorphology of the Ustrzyki Górne area (Polish Eastern Carpathians)], Studia Geologica Polonica, 48: 1-92.

Tokarski, A. K. (1978), Orogenesis and morphogenesis of Outer Carpathians and plate tectonics, Studia Geomorphologica Carpatho-Balcanica, 12: 29-43.

Twidale, C. R. (1978), On the origin of pediments in different structural settings, American Journal of Science, 278: 1138-1176.

Twidale, C. R. (1983), Pediments, peneplains and ultiplains, Revue de Géomorphologie Dynamique, 32: 1-35.

Velikovskaya, E. M. (1968), Nekotorye problemy geomorfologii Vostochnykh Karpat [Selected problems of geomorphology of the Eastern Carpathians], Vestnik Moskovskogo Universiteta, seria geologia, 4: 24-28, [in Russian].

White, K. (2004a), Glacis d'erosion, in Goudie, A. S. (ed.), Encyclopedia of Geomorphology, Vol. 1, London, Routledge, 469-470.

White, K. (2004b), Pediment, in Goudie, A. S. (ed.), Encyclopedia of Geomorphology, Vol. 2, London, Routledge, 768-771.

Willett, S. D., Slingerland, R. and Hovius, N. (2001), Uplift, shortening, and steady state topography in active mountain belts, American Journal of Science, 301: 455-485.

Wójcik, A. (2003), Czwartorzęd zachodniej części Dołów Jasielsko-Sanockich (polskie Karpaty Zewnętrzne) [Quaternary of the western part of the Jasło-Sanok Depression (Polish Outer Carpathians)], Prace Państwowego Instytutu Geologicznego, 178: 1-148.

Wójcik, A. and Jugowiec, M. (1998), The youngest members of the folded Miocene in the Andrychów region (Southern Poland), Przegląd Geologiczny, 46 (8): 763-770.

Zoetemeijer, R., Tomek, Č. and Cloetingh, S. (1999), Flexural expression of European continental lithosphere under the western outer Carpathians, Tectonics, 18: 843-861.

Zuchiewicz, W. (1978), Czwartorzędowe ruchy tektoniczne a rzeźba przełomu Dunajca przez 
Beskid Sądecki [Quaternary tectonics and the relief of the Dunajec river gorge in the Beskid Sądecki Mts., Polish Western Carpathians], Rocznik Polskiego Towarzystwa Geologicznego, 48: 517-532.

Zuchiewicz, W. (1980), Młode ruchy tektoniczne a morfologia Pienin [Young tectonic movements and morphology of the Pieniny Mts., Polish Western Carpathians], Annales Societatis Geologorum Poloniae, 50: 263-300.

Zuchiewicz, W. (1983), Quaternary evolution of valleys in the Dunajec drainage basin (Polish Western Carpathians), Studia Geomorphologica Carpatho-Balcanica, 16: 27-49.

Zuchiewicz, W. (1984a), Ewolucja poglądów na genezę i wiek karpackich powierzchni zrównania [Evolution of views on origin and age of Carpathian planation surfaces], Przeglad Geologiczny, 32: 468-477.

Zuchiewicz, W. (1984b), The Late Neogene-Quaternary tectonic mobility of the Polish West Carpathians. A case study of the Dunajec drainage basin, Annales Societatis Geologorum Poloniae, 54: 133-189.

Zuchiewicz, W. (1987a), Ewolucja i strukturalne założenia sieci rzecznej Karpat $w$ późnym neogenie $i$ wczesnym czwartorzędzie [Late Neogene-Early Quaternary evolution and structural control of the Carpathian drainage pattern], in Jahn, A. and Dyjor, S. (eds.), Problemy mtodszego neogenu i eoplejstocenu $w$ Polsce, Wrocław, Ossolineum, 211-225.

Zuchiewicz, W. (1987b), Tectonics and climate versus relief evolution: old controversy and new arguments, Studia Geomorphologica Carpatho-Balcanica, 21: 183-202.

Zuchiewicz, W. (1988), Evolution of the eastern Beskid Niski Mts. and morphotectonics of the Polish Carpathians, Zeszyty Naukowe AGH, 1156, Kwartalnik Geologia, 13 (1987), 3-4:3-167.

Zuchiewicz, W. (1989), Neotectonics versus gravity and crustal thickness: a case study of the Polish Flysch Carpathians, Tectonophysics, 163: 277-284.

Zuchiewicz, W. (1991), On different approaches to neotectonics: A Polish Carpathians example, Episodes, 14: 116-124.

Zuchiewicz, W. (1995), Selected aspects of neotectonics of the Polish Carpathians, Folia Quaternaria, 66: 145-204.

Zuchiewicz, W. (2009), Neotectonics of the Polish Carpathians in the light of geomorphic studies: a state of the art, Acta Geodynamica et Geomaterialia, 6 (3): 291-308.

Zuchiewicz, W. (2010), Neotektonika Karpat polskich $i$ zapadliska przedkarpackiego [Neotectonics of the Polish Carpathians and Carpathian Foredeep], Wydawnictwa AGH, Kraków, 1-234, [in Polish].

Zuchiewicz, W. and Zasadni, J. (2010), Quaternary evolution of a Carpathian Foothills area: An example from the East Carpathians of Poland, Annales Societatis Geologorum Poloniae, 80: 327-345.

Paper first received: April 2011

In final form: July 2011 


\section{INFORMATION FOR AUTHORS}

The editors of Geographia Polonica invite theoretical and empirical contributions to human as well as physical geography, in broad terms. Articles are expected to be original and not yet published elsewhere unless in languages other than English.

MANUSCRIPTS. Manuscripts, in the English language, should be submitted to the Editor of Geographia Polonica (Institute of Geography and Spatial Organization, Polish Academy of Sciences, Twarda 51/55, 00-818 Warszawa, Poland).

As all manuscripts will be reviewed, therefore, authors are kindly requested to provide two hard copies of the complete text (main text, abstract, references, tables, illustrations) and one copy delivered in an electronic form in MS Word.

The manuscripts should be arranged in the following order. First sheet: title, full name of author(s), affiliation, full postal adress, e-mail address . Second sheet: abstract of no more than 100 words, key words (3-10) at the end of the abstract. Subsequent sheets: the main text of about 20-25 pages (in A4 format). Then on separate sheets: acknowledgement (if desired), notes, references, tables, illustrations, captions to illustrations.

The main text may be organized in sections under appropriate headings without numerals.

SPACING. Manuscripts should be printed with 1,5 lines spacing without indents; for paragraphs enter a line space.

REFERENCES should be printed in alphabetical sequence at the end of the text. Examples:

Articles from journals:

Perroux, F. (1950), Economic space:Theory and applications, Quarterly Journal of Economics, 64: 89-104,

Kotarba, A. (1992), Denudacja mechaniczna Tatr Wysokich pod wpływem opadów ulewnych [Mechanic

denudation in the High Tatra Mountains caused by downpours], Prace Geograficzne 195, Instytut Geografii

i Przestrzennego Zagospodarowania (IGiPZ), PAN: 191-208.

Books:

Stren, R.,White, R. and Whitney, J. (1992), Sustainable cities, London, Jessica Kingsley Publishers.

Chapters from books:

Dematteis, G. (1996), Toward a unified metropolitan system in Europe: Core centrality versus network distributed centrality, in Pumain, D. and Saint-Julien, T. (eds.), Urban networks in Europe, INED, John Libbey, Paris, 19-28.

Theses:

Elfring, T. (1987), Service employment in advanced economies, Unpublished Ph.D. thesis, Rotterdam, Erasmus University, School of Management.

References should be indicated in the text by listing, in parenthesis, the author's name followed by the data of publication, e.g. (Kowalski 1995) or (Kowalski and Brown 1996) or (Kowalski et al. 1997) if there are more than two authors (Note: all the authors should be listed in the references).

FOOTNOTES and NOTES should be referred to by superscript letters.

ILLUSTRATIONS should be supplied in one of the following formats:

- photographs: JPG, TIFF, EPS or PSD,

-maps, figures and diagrams should be presented as vector files in AI (Adobe Illustrator) or one of the format mentioned above.

Please ensure that the resolution is not lower than $300 \mathrm{dpi}$ and the lines are a minimum of 0.3 points thick. Please also supply printouts of illustrations that are to be presented, in black and white or in colours, in relation to the required final appearance in print.

TABLES should be printed on separate sheets and numbered sequentially with Arabic numerals (e.g. Table 1). Each table should be provided with a clear descriptive caption at the top and informative column headings.

EQUATIONS and SYMBOLS used in mathematical formulae must be clearly explained. Axes on graphs should be described clearly. Units and abbreviations used by authors should conform to the International List.

MEASUREMENTS should be given in metric units.

ACCEPTED MANUSCRIPTS. After acceptance for publication, authors will receive page proofs for approval before publication. The revised manuscript should be returned promptly to the Editor.

Articles accepted for publication in Geographia Polonica are not honoured financially. Authors of accepted articles will receive one copy of the journal free of charge.

Authors are responsible for indicating copyright as well as permission from the copyright holder to reproduce any texts, tables or illustrations for which copyright exists. 


\section{CONTENTS}

\section{VICTOR R. BAKER}

Global planetary change and catastrophic earth-surface evolution: Implications for modern geomorphological research

\section{MONIQUE FORT}

The Himalayas: From mountain building to landform evolution in a changing world

\section{ELŻBIETA GORCZYCA, KAZIMIERZ KRZEMIEŃ, MICHAŁ ŁYP}

Contemporary trends in the Białka River channel development in the Western Carpathians

\section{KENNETH J. GREGORY}

Impacts of fluvial land form evolution and global change in urban environments

\section{ANDRZEJ KOSTRZEWSKI}

The role of relief geodiversty in geomorphology

\section{ADAM ŁAJCZAK}

Contemporary changes in the relief of raised bogs on the example of the Polish Carpathians

\section{PIOTR MIGOŃ}

Geomorphic diversity of the Sudetes - Effects of structure and global change superimposed

\section{MARIO PANIZZA}

The Dolomites and their geomorphodiversity

\section{SUBIR SARKAR}

Evolution of the Paglajhora slump valley in the Shiv Khola Basin, the Darjeeling Himalaya, India

\section{SURENDRA SINGH, HIAMBOK J. SYIEMLIEH}

Prediction of runoff in the Um-U-Lah catchment of extremely humid area of Cherrapunji, India

JEF VANDENBERGHE, GEMMA VENHUIZEN, JOS DE MOOR

Concepts of dynamic equilibrium of interest for river management in the Lower Maas catchment

\section{WITOLD ZUCHIEWICZ}

Planation surfaces in the Polish Carpathians: Myth or reality?

ISSN 0016-7282 